\title{
Acción surrealista y medios de intervención. El surrealismo en las revistas, 1930 - 1939
}

\author{
Javier MAÑERo RoDICIO \\ CES Felipe II, Universidad Complutense de Madrid \\ javier.manero@ajz.ucm.es
}

Entregado: $19 / 9 / 2012$

Aceptado: 4/7/2013

\section{RESUMEN}

Sobre la base de un estudio previo, El surrealismo en las revistas 1919 - 1929, pero de forma autónoma, se aborda a continuación la segunda década surrealista, revisitada siempre al hilo de las revistas que aglutinaron al movimiento. Tras analizar desde Un cadavre la dimensión de la crisis del grupo hacia el cambio de década, asistimos a la adaptación del surrealismo a las extremas condiciones políticas de los años 30 con su revista El surrealismo al servicio de la Revolución. Pero también, y al mismo tiempo, al momento de su máxima difusión y aceptación, particularmente a través del arte. La revista Minotaure será la principal manifestación de este proceso, aunque también son tenidas aquí en cuenta otras cabeceras.

Palabras clave: Surrealismo, Revistas de arte, A. Breton, G. Bataille, Le surréalisme au service de la Révolution, Documents 34, Minotaure, Cahiers d'Art.

\section{Surreal action and means of intervention. Surrealism in the magazines, from 1930 to 1939}

\begin{abstract}
Following on from the previous study, Surrealism in Magazines 1919 - 1929, the second Surrealist decade is now focussed on - at all times with regard to the magazines that united together around the movement. After analysing in Un cadavre the effects of the crisis of 1929, we witness Surrealism's adaptation to the extreme political panorama of the 1930's with the magazine Surrealism in the service of the revolution. At the same time, moreover, it is the period of Surrealism's most widespread dissemination and popularity, in particular through its art. Minotaure would be the foremost expression of this process, though the study takes into account other publications too.
\end{abstract}

Key words: Surrealism, Art Magazines, A. Breton, G. Bataille, Le surréalisme au service de la Révolution, Documents 34, Minotaure, Cahiers d'Art. 
"Ganar las fuerzas de la embriaguez para el servicio de la revolución: en torno a esto gira el surrealismo tanto en sus libros como en sus empresas. Tal es lo propio de su empeño." Walter Benjamin, $1929^{1}$

Las páginas que siguen insisten en las revistas del surrealismo. Pero no tratan tanto de revelar en ellas recovecos aún poco transitados, aunque todavía existen, como de aportar una visión amplia y coral de aquellos medios e incluirlos orgánicamente en la acción siempre total de los surrealistas. Iluminar la vida de los surrealistas con el foco de sus proyectos editoriales de grupo, con la vida de sus revistas. Con ello se quiere contribuir a una historiografía escasa, al menos en lengua española, cual es la centrada, muy específicamente, en el análisis y descripción de aquellas revistas en su conjunto. En esta ocasión ${ }^{2}$ se va a abordar la segunda década del surrealismo, cuando este, al tiempo que integra la acción política, alcanza su máxima difusión a través de varias revistas, no necesariamente surrealistas. Entre estos medios, los aquí considerados serán los de lengua francesa vinculados en algún momento al grupo liderado por André Breton. Sin descuidar otros aspectos relevantes, como los que enlazan surrealismo e historia, la progresiva apuesta por lo visual en las revistas tratadas será tenida especialmente en cuenta.

\section{El surrealismo tras el Segundo manifiesto. Crisis y refundación}

[Fig. 1 a, b.] La disidencia de Documents: Un cadavre.- En diciembre de 1929 se publicaba el $n^{\circ} 12$ y último de La Révolution surréaliste (LRS). En él veía la luz un extenso manifiesto mediante el cual André Breton establecía los términos del compromiso revolucionario del grupo y hacía una inapelable llamada general al orden surrealista. Ante la dispersión de personalidades relevantes del surrealismo a lo largo de ese mismo año, Breton detalla para cada uno de ellos sus desviaciones, deteniéndose especialmente en aquellos que se habían aproximado al entorno de Georges Bataille, sin duda el polo antagónico más intenso. El tono recriminatorio hacia estos antiguos compañeros es duro: "Dispuestos a tomar salida en la carrera que, como hemos visto, organiza M. Bataille, están los señores Desnos, Leiris, Limbour, Masson y Vitrac. (...) Creo que es extremadamente significativo ver que de nuevo se reúnen todos aquellos a quienes una tara u otra apartó de su primera actividad definida, ya que parece muy probable que tan solo tengan en común su resentimiento"3. Estas palabras del Second manifeste du surréalisme se hallan en un apartado resaltado con

1 BENJAMIN, W. (2007). El surrealismo. En TIEDEMANN, R. y SCHWEPPENAUSER, H. (Eds.). Walter Benjamin, Obras, libro II/vol. 1 (301-316, p. 313) Madrid: Abada Editores.

2 Este trabajo sobre las revistas del surrealismo es continuación de MAÑERO, J. (2012). Acción surrealista y medios de intervención. El surrealismo en las revistas, 1919 - 1929. De Arte, 11, 185-222, correspondiente a la década Dadá-surrealista. Ambos estudios se ciñen a ciclos vitales del movimiento perfectamente diferenciados y netamente divididos por acontecimientos internos coincidentes con el cambio de década, lo que permite abordarlos con mucha independencia.

3 BRETON, A. (1929, diciembre). Seconde manifeste du surréalisme. La Révolution surréaliste (París), $12,1-17$, p. 16. 

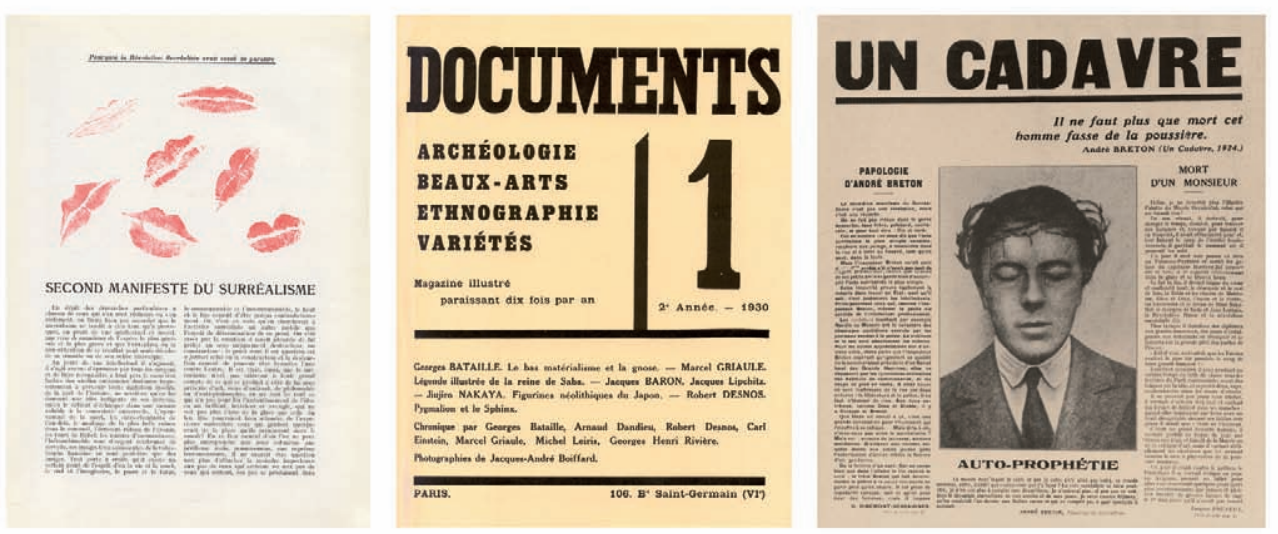

Fig. 1. Consecuencias del Second manifeste: La disidencia de Documents.-a) Página inicial del Second manifeste du surréalisme (nota 3); b) Cubierta de la revista Documents, $\mathrm{n}^{\circ} 1$, 1930 (nota 4); c) Página inicial del panfleto Un cadavre (notas 8 y 9).

el misterioso título: "Exijo la ocultación profunda y verdadera del surrealismo", apartado que culmina el manifiesto y que se dedica exclusivamente a lo que, en definitiva, parece ser uno de los objetivos más urgentes del texto: desprestigiar al solitario pero admirado Bataille que un año antes había puesto en marcha la revista Documents (1929-1930) ${ }^{4}$. Bataille era una personalidad en el margen, ajeno al surrealismo, pero de una intensidad intelectual profundamente subversiva que atrajo rápidamente hacia su inclasificable y poderosa revista a los poetas y artistas que ahora Breton, en realidad, echa profundamente de menos para su proyecto. Era necesario, para alcanzar el citado objetivo, anatemizar toda colaboración con el erudito paleógrafo y, con tal propósito, nadie queda al margen de ácidas críticas: Roger Vitrac es desahuciado sin más para la causa surrealista; en cuanto a Robert Desnos, tras recordar los admirables servicios prestados, se relata su actual decrepitud poética y vital -publica en Bifur y se ha permitido nombrar a un bar Maldoror- para concluir que "al no esperar (ya) nada de él, lo exoneramos de cuantas obligaciones pudo contraer, no hace mucho, para con nosotros". Pero es a Bataille para quien se reserva un comentario realmente extenso y elaborado. Breton repasa uno por uno sus artículos de Documents descalificando lo que entiende como una constante repetición de ideas carentes de originalidad, propias

4 Documents. (Archéologie. Beaux-Arts, Ethnographie, Variétés). Editada en París con periodicidad mensual, 15 números entre 1929 y 1930 ( $1^{\text {a }}$ serie). Formato: 21 x $27 \mathrm{~cm}$. Dirección efectiva de Georges Bataille. Reimpresión de la $1^{\mathrm{a}}$ serie completa en dos volúmenes: Documents $n^{\circ} 1$ à 7,1929 et $n^{\circ} 1$ à 8,1930 . (1991). Paris: Editions Jean Michel Place. Introducción de Denis Hollier: La valeur d'usage de l'impossible. A pesar de estos acontecimientos, Documents marcará profundamente al surrealismo, Minotaure sería solo, como veremos, la manifestación más explícita de ello. Posteriormente, con su recuperación hacia finales de los años 70 del pasado siglo, determinará la re-asimilación posmoderna del surrealismo. Dos estudios críticos monográficos sobre Documents son: DIDI-HUBERMAN, G. (1995). La ressemblance informe ou le gai savoir visuel selon Georges Bataille. París: Macula.; BOIS, Y-A. y KRAUSS, R. (1996). L'informe : mode d'emploi. París: Centre Georges Pompidou. 
del bibliotecario que al fin y al cabo es: "M. Bataille, que durante las horas de trabajo maneja con prudentes manos de bibliotecario viejos, y a veces bellos, manuscritos, al llegar la noche se harta con las inmundicias que le gustaría contuvieran aquellos (...)". Breton encuentra tal interés anti-idealista de Bataille por lo bajo, manifiestamente patológico: "M. Bataille asegura que de todo cuanto hay en el mundo tan solo quiere prestar atención a lo más vil, a lo más desesperanzador, a lo más corrompido"”.

[Fig. 1 b, c.] Con el Second manifeste un ciclo se cierra y con él la revista que lo sostuvo, LRS. La consumación de la inevitable escisión promovida por la diatriba bretoniana se produce inmediatamente, el 15 de enero de 1930, con el panfleto Un cadavre que desde el círculo de Documents se lanza agriamente contra Breton. Sus textos están firmados por todos los antiguos surrealistas ahora colaboradores de Documents, además de por el propio Bataille. Con el tiempo, hacia 1954, éste no se sintió orgulloso de aquel episodio y quiso determinar el papel que cada uno jugó, aclarando contra la opinión extendida, que él no fue su promotor, sino mero organizador en lo relativo a la edición ${ }^{6}$. Habría sido Robert Desnos quien planteara en primer lugar la necesidad de responder a las acusaciones de Breton, ideando tomar como modelo el hiriente panfleto que en octubre de1924 lanzó el grupo contra Anatole France -prohombre de la Francia del momento que acababa de morir- titulado precisamente Un cadavre: "iAnatole France ha muerto!”; "Tengo a todo admirador de Anatole France por un ser degenerado", se proclamaba ${ }^{7}$. A Breton se le aplicaría en el actual Un cadavre el papel de A. France. El grupo se sumó a la idea con un entusiasmo burlesco hasta la crueldad. Bajo los grandes caracteres del título se cita una frase que el propio Breton dedicara al prohombre satirizado: "Hay que evitar que, muerto, este hombre haga más polvo.", después, un gran retrato de Breton con los ojos cerrados y coronado de espinas ${ }^{8}$. "Auto-profecía" se indica, pues el difunto profeta Breton tenía justamente 33 años en ese momento. Los ataques de, uno por uno, todos los antiguos surrealistas se sucedían furibundos a continuación. Bataille tituló el suyo: Lion Châtré, (León castrado) destacando en gran tipografía: "Aquí yace el buey Breton, el viejo esteta, falso revolucionario con cabeza de Cristo". A pesar de la gravedad de lo escrito en su manifiesto, Breton no parecía esperar semejante reacción de los excomulgados. Lo cierto es que, según varios testimonios, quedó profundamente afectado y creyó que todos le abandonarían; incluso el suicidio no habría sido

5 BRETON, A. (1929, diciembre). Op. cit., p. 16.

6 BATAILlE, G. (1969, octubre). Interview. Le Pont de l'Epée (París), 41, 143-145.

7 Doc. colectivo. (1980). Un cadavre (1924). En PIERRE, J. (Ed.), Tracts surréalistes et déclarations collectives (19-25). Vol. I, 1922-1939. París: Le terrain vague. Se trata de una fuente imprescindible en los estudios sobre surrealismo. También en el presente. Los documentos contenidos en esta recopilación están disponibles en: http://melusine.univ-paris3.fr/Tracts_surr_2009/Tracts_I_2009.htm.

8 Doc. colectivo. (1980). Un cadavre (1924). En PIERRE, J. (Ed.), Op . cit., (19-25, p. 24). Boiffard aplicó la corona de espinas a una imagen de Breton entresacada del fotomontaje Je ne vois pas la... cachée dans la forêt aparecido pocas semanas antes en el último número de La Révolution surréaliste -el mismo que contenía el Second manifeste- donde se presentan los componentes del grupo surrealista con los ojos cerrados alrededor de una pintura de Magritte.

9 Doc. colectivo. (1980). Un cadavre (1930). En PIERRE, J. (Ed.), Op. cit., (132-148, p. 146). 
ajeno a sus pensamientos ${ }^{10}$. Pero no fue abandonado y Breton recupera rápidamente su afición polémica. En febrero de 1930 publica una breve selección de opiniones sobre su persona firmadas por los mismos antes de Un cadavre y posteriormente en el propio manifiesto: "Preocupado por la moral, es decir por el sentido de la vida, no por la observancia de las leyes humanas. Breton, por su amor a la vida exacta y la aventura, recupera el sentido propio de la palabra "religión"; "Y la última vanidad de este fantasma será apestar eternamente entre los hedores del paraíso prometido ante la próxima y segura conversión del pájaro (faisan) André Breton". Tal se consignaba, por ejemplo, acerca de las sucesivas opiniones de Robert Desnos ${ }^{11}$.

[Fig. 2 a.] Refundación: Le surréalisme ASDLR-Superada la amargura e, indudablemente, perdidas para la causa surrealista gentes irremplazables como: Baron, Boiffard, Desnos, Leiris, Limbour, Morise, Prevert, Queneau, Ribemont-Dessaignes, firmantes de Un cadavre, que se unen a los expulsados en 1926: Artaud, Soupault y Vitrac, o a Naville y Masson, paradójicamente, vemos resurgir con fuerza un nuevo grupo surrealista, más bretoniano e integrado que nunca a pesar de la diversidad de procedencias e intereses. Los artistas, que tan difícil encaje tenían todavía en 1924 entre muchos literatos del grupo, rescatan al surrealismo y le dan un nuevo impulso: Dalí y Buñuel, que acaban de desembarcar brillantemente en París con Le chien andalou (1929), se suman entusiastas, también Giacometti tras haber sido valorado en Documents por Michel Leiris ( $\mathrm{n}^{\circ}$ 4/1929), Duchamp y Tzara vuelven y, en general, la refundación del proyecto impulsa al grupo hacia una nueva etapa. En marzo del mismo año 1930 se lanza una nueva declaración colectiva -tract- que anuncia la determinación de continuar y de hacerlo desarrollando las propuestas bretonianas con un nuevo proyecto editorial: "Decididos a usar, es decir a abusar en toda ocasión de la autoridad que da la práctica consciente y sistemática de la expresión escrita u otra, solidarios en todos los aspectos de André Breton y resueltos a transformar en 'aplicación' las conclusiones que se imponen a la lectura del Segundo manifiesto del surrealismo, los abajo firmantes, que no se hacen ninguna ilusión sobre el alcance de las revistas 'artísticas y literarias', han decidido aportar su concurso a una publicación que bajo el título: LE SURREALISME AU SERVICE DE LA RÉVOLUTION no solamente les permita responder de una forma actual a la canalla que dice dedicarse al oficio de pensar, sino que preparara el giro definitivo de las fuerzas intelectuales hoy vivas en provecho de la fatalidad revolucionaria" ${ }^{12}$.

[Fig. 2 b.] Breton, Éluard y Aragon fundan una publicación radical incluso en su sobriedad gráfica. Su cubierta blanca solo porta: el nombre de la revista, un extraño emblema ocultista y el número del fascículo; todo ello en una extraña tinta verdosa que hay que "usar": "Cubierta procesada con Radiana. (Exponer fuertemente a la luz y mirar en la oscuridad)", se explica por detrás. Le surréalisme au service de la

10 LEINER, J. (1976). Les chevaliers du Graal au service de Marx. En Le surréalisme au service de la Révolution (Reimpresión) (i-xx, p. vii). París: Jean-Michel Place.

11 BRETON, A. (1980). Premier priere d'insérer du "Second manifeste du surréalisme". En PIERRE, J. (Ed.), Op. cit., (149-130, p. 149). Conocido como Avant et après du Second manifeste du surréalisme.

12 Doc. colectivo. (1930, marzo). Priere d'insérer pour "Le surréalisme au service de la Révolution". En BRETON, A et al. (1930, julio). Le surréalisme au service de la Révolution, 1, (hoja inserta). 

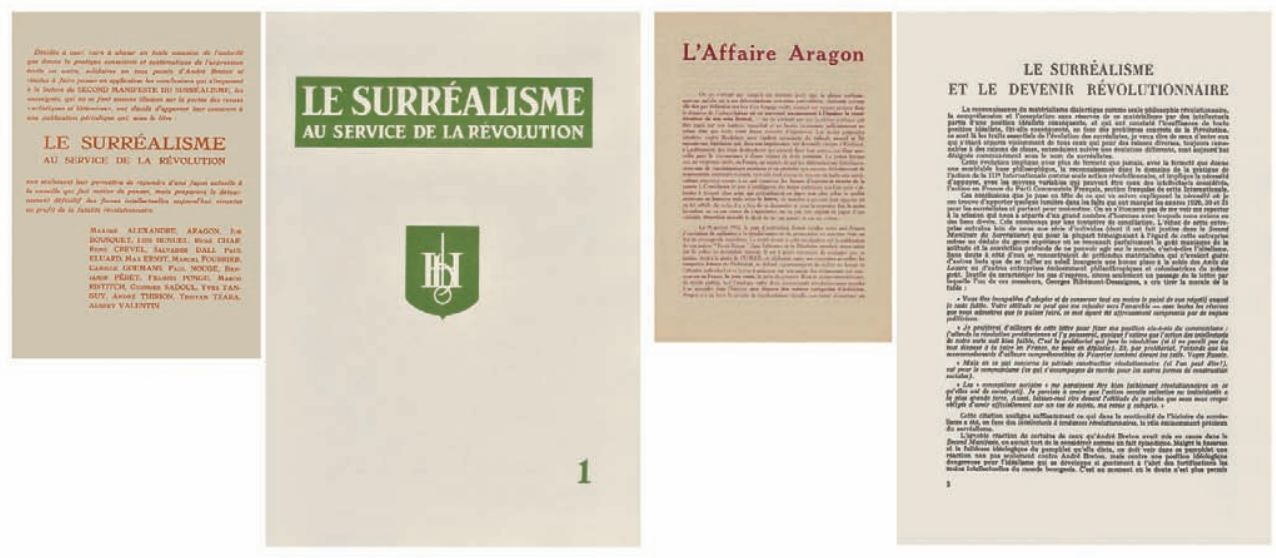

Fig. 2. Le surréalisme au service de la Révolution: Compromiso político.- a) Panfleto anunciando la revista (nota 12); b) Cubierta del $n^{\circ} 1$ (nota 13); c) Panfleto contra la inculpación de Aragon; d) Explicación de Aragon sobre su posición política, no 3 (nota 19).

révolution ${ }^{13}$ (LS.ASDLR) manifestará a lo largo de sus seis entregas, hasta mayo de 1933, una precisa voluntad de poner en obra la exigencia revolucionaria del nuevo manifiesto. Breton, que en este caso actúa desde el primer momento como director único de la revista, potenciará especialmente la nómina de los polemistas políticos con nombres como Georges Sadoul, Maxime Alexandre, Pierre Unik o André Thirion que refuerzan su propia acción y la de Aragon, artífice del título de la nueva publicación. Éluard, Péret, Crevel, Char o Valentin, no menos comprometidos, actúan más específicamente desde la poesía. Exactamente en la primera página, en un acto de compromiso inequívoco, y pareciera que para conjurar cualquier desvío en la praxis revolucionaria, se da respuesta a un telegrama de una asociación literaria soviética: "Camaradas, si el imperialismo declara la guerra a los soviéticos nuestra posición será conforme a las directivas de la Tercera Internacional posición de miembros del Partido comunista francés (...) En situación actual de conflicto no armado creemos inútil esperar para poner al servicio de la revolución los medios que nos son más propios" 14 .

13 Le surréalisme au service de la Révolution. Órgano del grupo surrealista editado en París. 6 números entre 1930 y 1933. Formato: 20,5 x 29,5 cm. Director: André Breton, gerente: Paul Éluard. Algunos colaboradores: Louis Aragon, Luis Buñuel, Salvador Dali, Max Ernst, Paul Nougé, Benjamin Péret, Yves Tanguy, etc. Reimpresiones: Le Surréalisme au service de la révolution (1970). New York: Arno Press. Le Surréalisme au service de la révolution $(1976,2003)$. París: Editions Jean-Michel Place. Introducción de Jacqueline Leiner. No se ha encontrado un libro monográfico sobre esta revista. Lo aportado por la citada introducción de J. Lenier se encuentra entre lo más centrado. Por supuesto, en obras más generales sobre surrealismo puede hallarse infinidad de referencias; es el caso, por ejemplo, de: SPIES, W. (Ed.) (2002). La Révolution surréaliste (343-344). París: Centre G. Pompidou, o CHEVREFILS-DESBIOLLES, Y. (1993). Les revues d'art à Paris, 1905-1940 (87-89). París: Ent'revues.

14 Doc. colectivo. (1930, julio). Télégramme envoyé à Moscou. Le surréalisme au service de la Révolution, 1, p.1. 


\section{Le surréalisme ASDLR: las revoluciones comunicantes}

Entre el Partido del sueño y el Partido comunista.- Si en el anterior proyecto editorial, $L R S$, se proponía un rencuentro con lo real guiado por metodologías exactas, científicas, en su capacidad para sustraerse a las pantallas interpuestas por la cultura y la razón, ahora esa realidad es social e insoslayable, es la Europa del ascenso de los fascismos. El surrealismo es revolucionario si se dirige al mundo de la vida para transformarlo, por lo tanto, "el surrealismo no se escribirá, no se pintará, se vivirá" y su finalidad es propiciar el cumplimiento del destino del hombre, según proclama Breton en Les Vases communicants (1932). Así, tal vez no sea la revolución surrealista la que esté al servicio de la marxista-leninista, tal vez esta última sea, en realidad, el medio necesario para el advenimiento de la primera, auténtica finalidad. Este juego de equilibrios, esta dialéctica comunicante poética/política - acción subjetiva/ acción social es, precisamente por su improbable cumplimiento, una proposición vanguardista absoluta, "punto extremo de la experimentación surrealista", tal como lo expresa Jacqueline Leiner ${ }^{15}$. Este, aunque aparentemente paradójico, alto grado de coherencia alcanzado por el grupo surrealista de 1930-1933, hará exclamar a Breton tiempo después en relación a sus revistas: "Le surréalisme ASDLR (...) es de lejos la más rica, en el sentido en que nosotros lo podemos entender, la más equilibrada, la mejor construida y también la más viva (de una vida exaltante y peligrosa). Es en ella donde la llama del surrealismo ha dado toda su medida: durante un tiempo unos y otros solo han mirado esta llama y no han temido consumirse en ella"16.

[Fig. 2 d.] El compromiso de la revolución surrealista con la proletaria que quiere ilustrar la nueva revista se concreta en su colaboración con los órganos del comunismo internacional, en su caso el Partido comunista francés, PCF, el mismo que ya en 1927 había expulsado, apenas afiliados, a Breton y otros del grupo y que tampoco ahora comprendía por qué a los surrealistas no les bastaba con ser marxistas ${ }^{17}$. Comprendidos o no, tal compromiso político es durante algún tiempo una prioridad e igualmente ocasión de conflictos, tal como ilustran los acontecimientos. Reparemos, en primer lugar, en el comisionado del grupo surrealista a la $2^{\mathrm{a}}$ Conferencia internacional de escritores revolucionarios, celebrada en Kharkov (URSS) a finales de 1930. Georges Sadoul y Aragón partieron al Congreso con la encomienda expresa de Breton de defender la "línea surrealista", pero justo antes de su vuelta firmaron una declaración según la cual se comprometían a supeditar la actividad literaria surrealista y las nociones del Second manifeste a las directrices del Partido. El encargo de Breton se había cumplido a la inversa. Sin embargo, Aragon tarda en explicarse y solo lo hace, tras presiones surgidas del grupo, un año después con el texto Le surréalisme et le devenir révolutionnaire, aparecido en el $\mathrm{n}^{\circ} 3$ (12/1931) de LS.ASDLR: "En las actuales condiciones es imposible el devenir del surrealismo independientemente

15 LEINER, J. (1976). Op. cit., p. vii.

16 BRETON, A. (1952). Entretien radiophonique avec André Parinaud (nº XI). En PARINAUD, A. (Ed.). Entretiens 1913-1952 (147-156, p. 153-154). París: Gallimard.

17 "'Si es marxista no tiene ninguna necesidad de ser surrealista' se le dice a uno de los nuestros" BRETON, A. (1929, diciembre). Op. cit., p. 6. 
del materialismo dialéctico, y es igualmente imposible considerar el devenir de los surrealistas al margen del proletariado, y puede, por lo tanto, considerarse como un hecho cumplido el paso de los surrealistas [desde su clase burguesa] al lado del Proletariado en su lucha revolucionaria contra la burguesía"18. Una conclusión, en principio, acorde con el nuevo manifiesto constitucional del surrealismo. La explicación de Aragon es aceptada y la relación con el grupo se normaliza. Pero indudablemente el texto contiene una ideología acerca de la forma concreta que debía adquirir el compromiso: "El valor revolucionario de la experimentación surrealista radica en el progreso que insufle al materialismo dialéctico" se afirmaba poco antes, y si bien de este modo queda resuelta la contradicción del surrealismo, lo hace a costa del partido del sueño, porque en aquel contexto, materialismo dialéctico significaba, de hecho, PCF.

[Fig. 2 c.] El caso Aragon.- El respiro de Breton acerca de las convicciones surrealistas de su gran amigo apenas dura un mes desde que fuera publicada tal explicación. A comienzos de 1932 el Gobierno encausa a Aragon por graves delitos de sedición e incitación a la violencia a cuenta de Front rouge, un poema publicado el año anterior en una revista literaria soviética: "Fuego sobre Leon Blum (...) Fuego sobre los amaestrados osos socio-demócratas" ${ }^{19}$. Los surrealistas toman su defensa en el tract, L'Affaire Aragon que L'Humanité acusa de oportunista. Aragon, entre dos fuegos, rechaza públicamente la defensa ofrecida por los surrealistas. El equilibrio era insostenible, sin embargo, la presión continúa. Ahora a cuenta de Rêveries, un texto de Dalí aparecido en no 4 (12/1931) de LS.ASDLR. Su tono, lleno de perturbadas y perturbadoras visiones eróticas y masturbatorias, pareció pornográfico a la Comisión de control del PCF -"Solo buscan complicar las relaciones, tan simples y tan santas, del hombre y la mujer... apesta a descomposición burguesa" ${ }^{20}$ - que conminó a Aragon y otros surrealistas allegados al partido, a desautorizarlo. Breton obvió tal dictado haciendo insostenible la posición de los más próximos al aparato comunista, Aragon, junto a Sadoul, Alexandre y Unik, es decir, quienes concretaban la acción política del grupo surrealista, lo abandonan. El grupo da forma a esta ruptura, sin duda la más grave de esta segunda década surrealista, con el manifiesto Paillasse! (03/1932) condenando y expulsando a los disidentes; Breton no es capaz de firmar la expulsión de su amigo.

Breton ponía una vez más, como ya ocurriera en la época de Clarté $^{21}$, límites al control del PCF sobre las actividades surrealistas pero, también como siempre, con la firme voluntad de mantenerse en los órganos políticos del proletariado. En febrero

18 ARAGON, L. (1931, diciembre). Le surréalisme et le devenir révolutionnaire. Le surréalisme au service de la Révolution, 3, 2-8, p. 8.

19 PICON, G. (1981). Diario del surrealismo. Ginebra: Skira-Destino, p. 124.

20 LEINER, J. (1976). Op. cit., p. xvi

21 A lo largo de 1925 se produce una aproximación al grupo marxista Clarté y a su revista de reflexión política Clarté (1921-1928). Surgieron entonces las primeras tensiones acerca del grado de participación y dependencia política de la actividad surrealista. Estos y otros precedentes propios de la primera década surrealista, se abordan, siempre desde las revistas, en el citado estudio: MAÑERO, J. (2012). Op. Cit. En todo caso, la bibliografía sobre la actividad y dimensión política de los surrealistas es amplia, por citar títulos muy específicos: BONNET, M. (1988). Vers l'action politique. Paris: Gallimard; BÉHAR, H. (2002). Le surréalisme dans la presse de gauche (1924-1939). Paris: Paris-Méditerranée; ASHOLT, W. y SIEPE, H. T. (Ed.) (2007). Surréalisme et politique - Politique et surréalisme. Amsterdam-New York: Rodopi. 

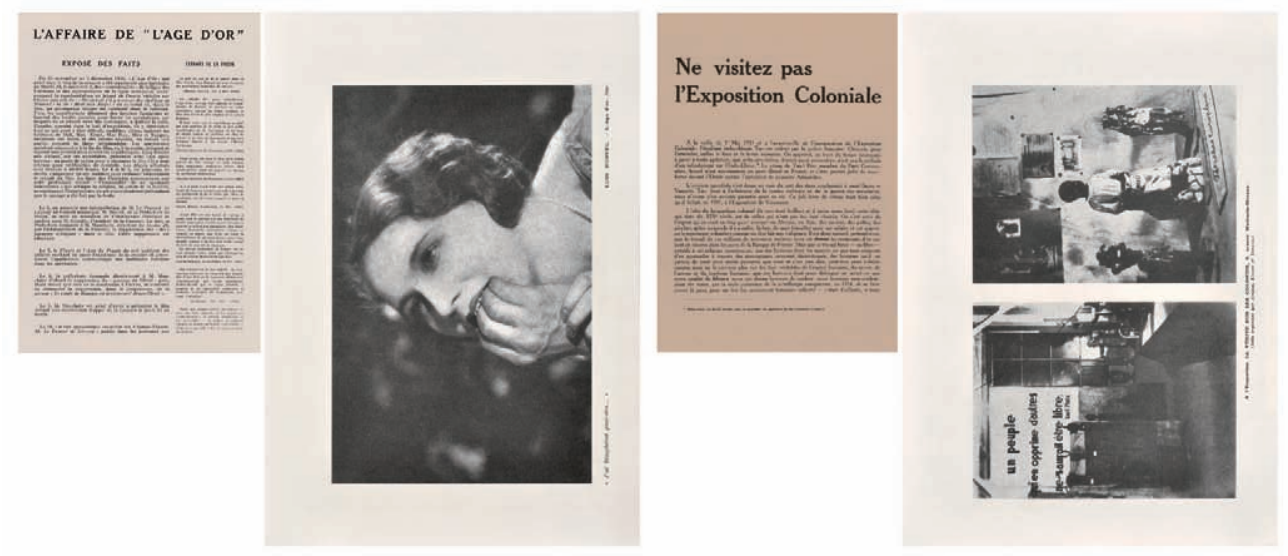

Fig. 3. Le surréalisme au service de la Révolution: Acción de grupo.- a) Panfleto sobre los ataques y posterior prohibición de L'Âge d'Or (nota 25); b) Fotograma de L'Âge d'Or, no 1 ; c) Panfleto contra la Exposición Colonial (nota 26); d) Imágenes de la contra-exposición surrealista, $\mathrm{n}^{\circ} 4$ (nota 27 ).

de 1933 participa en el Congrès de l'Association des écrivains et artistes révolutionnaires, la A.E.A.R. ${ }^{22}$, enfatizando su compromiso expreso con el marxismo y la clase obrera, como es claro en el extenso fragmento de su conferencia transcrito en el $\mathrm{n}^{\circ} 5$ de LS.ASDLR bajo el decoroso título: A propos du concours de littérature prolétarienne organicé par "L'Humanité". De poco sirve. En el mismo no 5 de la revista -que sale junto al $n^{\circ} 6$ y último el 15 de mayo de 1933-, se publica una carta de Ferdinand Alquié dirigida a Breton cuya breve descalificación de Aragon y crítica a la intelectualidad soviética: "El viento de cretinización sistemática que sopla de la URSS" ${ }^{23}$ va a ser suficiente para que Breton, Éluard y Crevel sean expulsados de la A.E.A.R. por incluir la carta en la revista. La stalinización de la URSS, y por tanto del PCF, los ataques a Trotsky y las purgas que jalonarían los años siguientes hasta los Procesos de Moscú, rebajarían la ansiedad por acompasar la acción surrealista a la del PCF, lo que potenciará otros cauces de acción política, por lo demás, siempre practicados por el grupo.

[Fig. 3.] La acción sobre el presente: censura, colonialismo y heroínas.- Asambleas, procesos, manifiestos o declaraciones públicas ante acontecimientos concretos: la nueva revista, como su predecesora, fue partícipe y se hizo eco de estas activida-

22 Según la imprescindible Cronología preparada por Marguerite Bonnet para su edición de las Obras completas de André Breton, este y Thirion redactaron los estatutos de esta asociación, proponiéndolos al PCF en noviembre de 1930. Los surrealistas, por lo tanto, siempre estuvieron integrados en ella. BONNET, M. (1988). Chronologie. En BRETON, A. (Ed. M. Bonnet et alt.). Oeuvres complètes (Tome I). París: Gallimard. p. lvii.

23 ALQUIÉ, F. (1933, mayo). A André Breton. Le surréalisme au service de la Révolution, 5, p. 43. Ferdinand Alquié, filósofo y simpatizante del surrealismo, es el autor de Philosophie du surréalisme (1955): ALQUIÉ, F. (1974). Filosofía del surrealismo. Barcelona: Barral. 
des. El cuadernillo de imagen del $\mathrm{n}^{\circ} 1$ (7/1930), de $L S . A S D L R$ se inicia precisamente con cuatro fotogramas de L'Âge d'Or de Buñuel, allí están a toda página, entre otros, dos momentos de la escena de amor ante la estatua de Diana, hoy emblemáticos. Es una primicia que se anticipa a la presentación pública del film en noviembre de 1930 en la sala Studio 28, ocasión que reunió la rendida admiración del surrealismo. Se exponen numerosas pinturas en la sala y se edita un amplio programa: L'Âge d'Or (11/1930), que constituye una verdadera revista compuesta por textos e ilustraciones del grupo al completo ${ }^{24}$. La notable repercusión del acontecimiento atrajo a los pocos días a las Ligas derechistas (Ligue des Patriotes y Ligue Anti-juive) que destrozaron la sala y varios de los cuadros, al tiempo que se desataba una virulenta campaña en la prensa que acabó con la censura de la cinta en una clara manifestación de las nuevas condiciones de la libertad en Francia. El grupo da cuenta de ello a comienzos del siguiente año en L'Affaire de l'Âge d'Or, un nuevo tract donde se exponen los hechos y se organiza un pequeño dossier de opiniones de prensa de toda tendencia. Poco después, en mayo de 1931, los surrealistas se pronuncian, como muchas fuerzas de izquierda, contra un gran evento nacional, la Exposition Coloniale internationale, mediante el tract, Ne visitez pas l'Exposition Coloniale: "A los discursos y a las ejecuciones capitales responded exigiendo la evacuación inmediata de las colonias y el encausamiento de los generales y funcionarios responsables de las masacres de Annam, de Líbano, de Marruecos y del África central"25. LS.ASDLR es testigo de esta oposición radical desde el primer número hasta el último y pueden rastrearse notas y artículos en tal sentido de Éluard, Crevel, Valentine, etc. Pero el documento más directo aparecerá en la página que cierra el $n^{\circ} 4$ (12/1931), con dos vistas de La Verité sur les colonies, que documentan esta contra-exposición ${ }^{26}$ organizada por Aragon, Éluard, Tanguy y Thirion en el mes de septiembre. En una de las imágenes se lee al pie de cierta imaginería cristiana: "Fetiches europeos".

[Fig. 4 c.] Algo más avanzado este inicio de década, hay que detenerse en dos asuntos profundamente representativos del sentir surrealista, y que vinculan la acción del grupo a los inicios, a 1923 cuando desde Littérature, Aragon tomaba la defensa de Germaine Berton, la anarquista homicida a cuyo alrededor se distribuían los surrealistas en la tabla de retratos aparecida en $\mathrm{n}^{\mathrm{o}} 1$ de $L R S^{27}$. Todas ellas heroínas surrealistas y homicidas procesadas con gran aparato público. A sus patronas asesinaron

24 Los textos e imágenes que componen esta manifestación colectiva así como las declaraciones posteriores sobre L'Âge d'Or pueden encontrarse en PIERRE, J. (Ed.). (1980). Op. cit., (155-169).

25 Doc. colectivo. (1980). Ne visitez pas l'Exposition coloniale. En PIERRE, J. (Ed.), Op. cit. (194-195). La exposición, organizada a imagen de la de 1925 e igualmente ambiciosa y propagandística, fue un gran acontecimiento orientado a mostrar al mundo la potencia imperial de la Grande France que acogía y daba a conocer como primicia en occidente infinidad de manifestaciones culturales de ultramar.

26 En ella se proponía un discurso en tres partes: crímenes de las conquistas coloniales; la URSS como ejemplo de integración de naciones; las culturas autóctonas asfixiadas por las misiones religiosas. Sobre este episodio y en general la posición surrealista ante el colonialismo consultar: SIEPE, H. T. (2007). "Ne visitez pas l'Exposition Coloniale" -quelques points de repères pour aborder l'anticolonialisme des surréalistes. En ASHOLT, W. y SIEPE, H. T. (Ed.), Op. cit. (169-180).

27 El retrato de Germaine Berton aparece rodeado de otros más pequeños correspondientes a 28 surrealistas y allegados. Este fotomontaje y su equivalente: Je ne vois pas la... cachée dans la forêt, abre y cierra, respectivamente, la colección de La Révolution surréaliste. Son manifestaciones del constante interés 

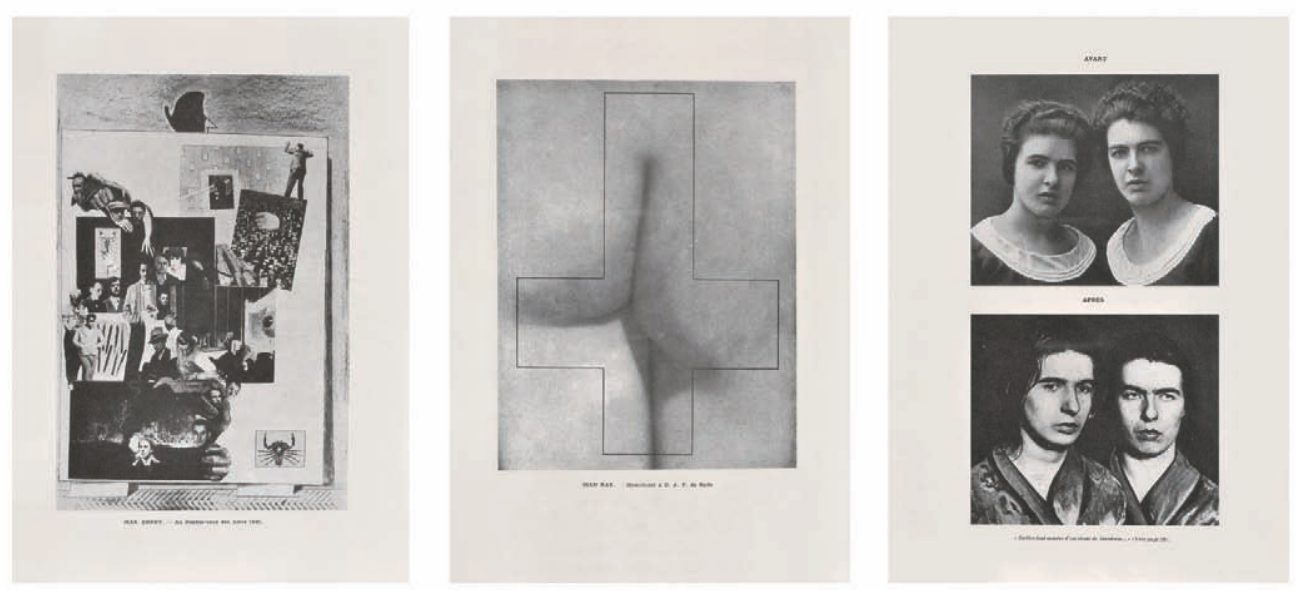

Fig. 4. Le surréalisme au service de la Révolution: La imagen.- a) Au rendez-vous des amis 1931, Max Ernst, nº 4 (nota 31); b) Monument à D. A. F. de Sade, Man Ray, nº 5; c) Avant, Après (Las hermanas Papin), $\mathrm{n}^{\circ} 5$.

las hermanas Papin a comienzos de 1933, con atroz precisión de cocineras e inmersas en un delirio nunca explicado: "Surgidas completamente armadas de un canto de Maldoror...", según afirman Éluard y Péret en el no 5 (5/1933) de LS.ASDLR. En la última página de este fascículo aparecen las hermanas, en un antes y un después: una imagen hermosa y juvenil de sus rostros, muy reproducida en la época, y otra exacta a la anterior en la disposición y proporciones, pero producto del montaje de dos fotografías policiales tomadas aún con las mismas ropas de la detención: las limpias batas con que se vistieron tras lavar la sangre ${ }^{28}$. Es sin duda una de las páginas más perturbadoras al tiempo que irónicas de la revista "clásica" de surrealismo. Una misma fascinación pero ahora unida a determinaciones políticas, movilizará a los pocos meses al grupo alrededor de otro caso de crónica negra. En agosto, la joven Viollet Nozière envenena a su padre, al que después acusa de incesto. La repercusión social es enorme, los surrealistas, como otros intelectuales de izquierdas, justifican la acción y convierten a la parricida en nueva musa a la que dedicarán una importante obra publicada ese mismo año 1933: Viollet Nozière. Definida en ocasiones como novela colectiva, reúne poemas y dibujos de gran parte de los componentes del grupo, incluidos los menos dados a la expresión política -Dalí, Giacometti, Arp-, en la reivindicación de la joven como víctima del paradigma patriarcal y nuevo ejemplo de la insondable y precisa intensidad femenina, fascinación mayor y recurrente del surrealismo.

por identificar surrealismo con acción revolucionaria de grupo al tiempo que con lo insondable, tan a menudo identificado en el amor y la mujer.

28 En el número 3-4 (12/1933) de Minotaure aparece una importante réplica de este caso: Motifs du Crime Paranoïaque. Le crime des soeurs Papin, segundo y último de los artículos de Jacques Lacan en la revista, un análisis en clave psicoanalítica del crimen a la luz de la homosexualidad de las hermanas. 
[Fig. 4 a.] La parte de la imagen y los artistas.- Como órgano del grupo surrealista, $L S . A S D L R$ mantuvo, pues, el compromiso político que dio formalmente sentido a su nacimiento. Pero, paralelamente, la revista se caracterizó por una diversidad de sensibilidades acorde con un grupo definitivamente heteróclito: poetas independientes como Tzara, Éluard, Char; artistas -pintores, escultores, cineastas, fotógrafos-; polemistas feroces como Aragon, Péret o Crevel: "Señor, tengo el honor de informarle que le tengo a usted por un puerco y un g..."; comunistas militantes, como ya vimos. Y tantos inclasificables como Heine, Caillois, Duchamp, etc. Max Ernst da fe de tal amalgama de gentes e intereses en su actualización: Au rendez-vous des amis $1931^{29}$, un collage-fotomontaje aparecido en el $\mathrm{n}^{\mathrm{o}} 4$ de la revista. En medio de tal diversidad supo situarse Breton y defender, como en el caso de Rêveries, la independencia de sus investigaciones dentro de la revista y del surrealismo. Muchos de esos autores irán apareciendo aquí y allá a lo largo del texto, y en tales ocasiones se les dedicará su espacio. Por el momento, observemos el tratamiento que LS.ASDLR otorgó al arte y la imagen.

[Figs. 3-5.] En la renovación de 1930, el arte se reveló especialmente resistente en el surrealismo, la atracción que el movimiento ejerce sobre artistas en todo el mundo traerá nuevas adhesiones constantemente y la percepción pública del movimiento comienza a ser visual, un proceso que se acelera con la llegada de Dalí. Incluso dentro del carácter sintético de este estudio, no es posible dejar de destacar el papel que el artista catalán comienza a adquirir desde el nacimiento de $L S . A S D L R$ y durante toda la década. Avalado ya por sus contribuciones en el último número de $L R S$, Dalí se revela en la nueva revista como renovador de la teoría surrealista al tiempo que nuevo referente artístico del movimiento. "Una actividad de tendencia moral podría estar provocada por la voluntad violentamente paranoica de sistematizar la confusión" ${ }^{30}$, el dispositivo paranoico-crítico queda ya bien descrito en L'Ane pourri, aparecido en el $\mathrm{n}^{\circ} 1(07 / 1930)$ de LS.ASDLR, donde su presencia artística se concreta con L'Homme invisible una suerte de puesta en obra del sistema presentado. Dalí pasa a constituir por sí mismo una polaridad particular, e incluso un cierto contrapeso a la autoridad bretoniana: "Puede considerarse, afirma José Vovelle, a Breton y a Dalí, como los dos polos antitéticos y complementarios del surrealismo de los años 30, el primero asumiendo la dimensión ética y política del movimiento bajo la égida de Marx y el segundo encarnando su lado "más freudiano" "31. Su arrolladora presencia teóricoliteraria y artística deviene imprescindible y constante en cada número de la revista. Breton y Aragon, aunque promotores del sesgo políticamente militante del grupo al que tan ajeno se mantuvo por lo general Dalí ${ }^{32}$, reconocieron siempre la importan-

29 Los presentes en este Rendez-vous renovado del grupo son: Tanguy, Aragon, Giacometti, Ernst, Dalí, Tzara, Péret, Buñuel, Éluard, Thirion, Char, Unik, Alexandre, Man Ray, Breton, Crevel y Sadoul.

30 DALÍ, S. (1930, julio). L’Ane pourri. Le surréalisme au service de la Révolution, 1, 9-12, p. 9.

31 VOVELLE, J. (1997). Les années trente du surréalisme. En Années trente en Europe: Le temps menaçant 1929-1939 (66-70, p. 66). París: Flamarion.

32 Dalí se implica con su firma en algunas manifestaciones colectivas que, ateniéndose a la letra, presupondrían su acuerdo con las posiciones políticas del grupo: Defensa pública del Second manifeste du Surréalisme (Second Priere d'insérer), L'affaire de "L’Âge d'Or", Misère de la poésie y Pallaise. Sin embargo, desde comienzos de 1932, fecha de las dos últimas citadas, relativas al caso Aragon, su firma no 
cia de su aportación: "La experimentación surrealista ha sido recuperada totalmente gracias al magistral impulso que le ha dado Salvador Dalí, cuya excepcional ebullición interior ha sido para el surrealismo durante todo este período un fermento inapreciable" 33 , afirmaba todavía Breton en mayo de 1934, en su célebre conferencia Qu'est-ce que le surréalisme?.

Mientras la nómina de poetas que llegan hasta $L S . A S D L R$ se redujo notablemente, la de los artistas se mantuvo y creció, estos, a diferencia de los primeros que tras colaborar en Documents nunca volvieron con Breton, alternaron en muchos casos ambos medios. Sin embargo, la financiación de $L S . A S D L R$ era tan frágil como la de su predecesora y, a pesar de que formaba parte del proyecto de Breton llegar con la nueva revista a un público amplio, las ventas resultaron notablemente inferiores a las del anterior título ${ }^{34}$. Aunque la obligada modestia editorial del proyecto no permitía paginar la imagen que en ese momento la dimensión artística ya demandaba, se articuló una solución que también habla de la madurez e independencia artística adquirida por el movimiento. Los grandes maestros aducidos antes al surrealismo y reproducidos abundantemente en $L R S$, Picasso, De Quirico, Klee, etc. desaparecen por completo y las escasas páginas disponibles se otorgan exclusivamente a los artistas y actividades del grupo. Buñuel, Man Ray, Dalí, Tanguy, Miró, Giacometti, Valentin Hugo, Ernst, Duchamp, Magritte y los propios poetas con sus objetos y collages, ocuparán los cuadernillos de cuatro hojas dispuestos al final de cada fascículo con reproducciones fotográficas a toda página. La imagen propuesta en ellos remite en su pie a alguno de los textos del número, o bien, como en el caso de las obras artísticas, constituye un hors-texte. En todo caso, la autonomía con que se muestran en su sucesión, es completa, el discurso de la revista adquiere una dimensión visual y plástica que antes faltaba y que afirma su intencionalidad con la abundante imagen de arte incluida. Los artistas, sin por ello dejar su actividad literaria y agitadora en páginas interiores, pueden finalmente manifestarse con el medio que les es más propio, y ello sin que la estética suplante a la acción, sin convertir la revolucionaria revista en revista de arte.

[Fig. 5.] Pero esta autonomía discursiva de la imagen basada en su segregación del texto, tuvo también por objeto recuperar la sobriedad: los contenidos sin más, lo adecuado a una revista de acción revolucionaria. Un cambio completo respecto a la discreta, pero constante y refinada interacción de las imágenes distribuidas esporádicamente entre los textos de LRS. En todo caso, el formato elegido era, precisamente, el más radicalmente opuesto al establecido por la coetánea Documents, con su ebria

vuelve a aparecer, precisamente en el momento de mayor actividad política del grupo: Légitime Défense, AEAR o Appel à la lutte (y otras manifestaciones antifascistas de 1934), no contaron con su participación. Sí firma en 1935 Du temps que les surréalistes avaient raison, documento abiertamente crítico con la deriva totalitaria de la URSS. A pesar de su flagrante distanciamiento ideológico, los surrealistas nunca renunciaran a la aportación artística de Dalí hasta la expulsión final de 1939.

33 BRETON, A. (1992). Qu'est-ce que le surréalisme? (Conferencia de Bruselas). En BRETON, A. (Ed. M. Bonnet et alt.), Op. cit., (225 262, p. 255).

$34 L S . A S D L R$ vendió 350 ejemplares de sus dos primeros números, frente a los 1050 vendidos del número 12 y último de La Révolution surréaliste. LEINER, J. (1976). Op. cit., p. xiii. Respecto a la financiación, cada partícipe del grupo aportaba según sus posibilidades económicas y trabajaba en la edición de la revista, corrección, sumarios, etc. 

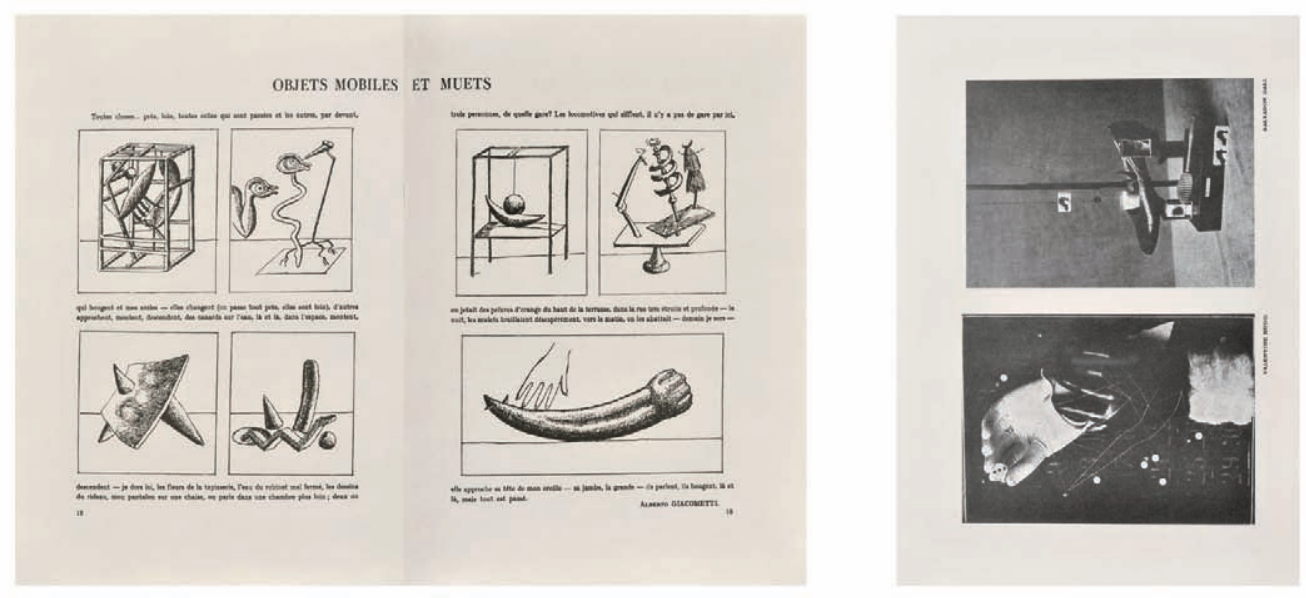

Fig. 5. Le surréalisme au service de la Révolution: El objeto en el no 3 (nota 68).- a) Pliego interior de Giacometti con texto y esculturas-objetos surrealistas; b) Objetos surrealistas de V. Hugo y S. Dalí, entre los presentados en las páginas de imagen.

y deslumbrante promiscuidad texto-imagen; un modelo este que, sin embargo, será después apropiado por completo en Minotaure. Por lo demás, aunque no muy frecuentemente, sí se incluyen dibujos y gráficos no fotográficos en páginas interiores cuando forman parte indisoluble de lo propuesto como artículo. Este formato ha dejado dos pliegos célebres: Formule de l'opposition hetérodoxe dans les domaines principaux, en el $\mathrm{n}^{\circ} 2$ (10/1930), donde Duchamp, que había sido reconvenido en el Second manifeste a jugar la verdadera partida, que no es de ajedrez, insiste en tal juego con varios diagramas de posiciones. Y, sobre todo, Objets mobiles et muets, de Giacometti integrado en el mismo $n^{\circ} 3(12 / 1931)$ con el que se inaugura la pasión surrealista por el objeto y cuyos contenidos en este sentido serán tenidos en cuenta después.

El 15 de mayo de 1933 aparecen simultáneamente -como ya ocurriera en diciembre de 1931 con los nos 3 y $4-\operatorname{los}^{\text {os }} 5$ y 6 de la revista, última entrega de $L S . A S D L R$. La débil financiación y distribución ya referidas, al tiempo que, en realidad, la desactivación del proyecto tras el distanciamiento del PCF y de Aragon, uno de sus máximos animadores, dieron al traste con esta publicación después de tres años de vida intensa. Le surréalisme au service de la Révolution es en propiedad, la última revista del grupo surrealista antes de la guerra, desde luego la última que realmente actuó como medio de intervención y órgano grupal periódico; con ella se cierra una etapa en su praxis organizativa y discursiva. Hasta ese momento tanto en los años Dadá -Littérature- como desde el primer manifiesto -La Révolution surréaliste-, contaron con órgano propio para difundir su acción revolucionaria, ahora en la madurez del grupo parecen requerirse otros medios, ampliar posibilidades editoriales, procurarse verdaderamente mayor difusión. Cosas que ni tan siquiera la economía de quien de hecho financió la última doble entrega, Paul Éluard, podía lograr. 


\section{La gran amplificación de Minotaure}

[Fig. 6 a, b.] La más lujosa revista, al servicio del surrealismo.- El prestigio del movimiento así como la rápida difusión y aceptación de sus propuestas artísticas, sitúa a los surrealistas en las antípodas de aquella exigencia de ocultación del Second manifeste. El surrealismo es objeto de curiosidad, y ello está en el origen de Minotaure $^{35}$, la próxima revista, aunque no órgano del grupo sí en definitiva surrealista y heredera de $L S . A S D L R$. Entre 1933 y 1939 contará con 13 números repartidos en 11 fascículos de gran formato y calidad bibliográfica. El editor suizo Albert Skira, especializado en cuidadas ediciones de arte, deseaba lanzar una revista, la más lujosa del momento, orientada al arte moderno y la cultura contemporánea y, sabiendo cuán difícil sería batir en su propio terreno, el del arte moderno, a la prestigiosa Cahiers d'Art, imagina como estrategia de diferenciación la asociación escándalo surrealistaarte moderno. Émile Tériade, crítico de arte y gestor del proyecto desde el primer momento, puso en práctica la idea sugiriendo la incorporación de Breton y de Bataille y con ellos sus respectivas experiencias editoriales. Pero la participación de Breton fue avalada también desde otros flancos: deseando garantizar el lanzamiento de la nueva revista, Skira propuso a Picasso protagonizar su primer número, el pintor pidió entonces que fuera Breton el encargado del texto para su reportaje sugiriendo, además, que se le integrase en el comité editorial de la revista ${ }^{36}$. Sin que ello significase entregar el control, el proyecto se abrirá a Breton y su grupo surrealista, al mismo tiempo que a Bataille y al extraordinario referente editorial de Documents, muy apreciado por Tériade. Este, por su parte, sumaba la experiencia de Cahiers d'Art, donde fue crítico y mano derecha de su creador Christian Zervos. Con tales mimbres se elabora la revista cultural más ambiciosa y bibliográficamente lujosa de los años treinta, pues incluso lo que no llegó a cuajar en tal alquimia, la difícil colaboración entre Breton y Bataille -a quien parece deberse el nombre de la nueva publicación ${ }^{37}$ - dejó un poso perdurable.

Considerando que su aparición se produjo el 1 de junio de 1933, solo 15 días después de la distribución de la última entrega de $L S . A S D L R$, y ya con una completa participación de los surrealistas, hay que pensar que el ofrecimiento de Skira a Breton contribuyó al fin de la revista del grupo, que de alguna manera se veía sustituida por la nueva publicación. En todo caso el salto era atrevido y generó tensiones en su seno. En un primer momento solo Breton percibió la oportunidad de renovar la ac-

35 Minotaure. (Revue artistique et littéraire). Editada en París, 13 números en 11 fascículos publicados con periodicidad irregular entre 1933 y 1939. Formato: 31,7 x 24,3 cm. Editor y director: Albert Skira; director artístico: Émile Tériade; comité de redacción variable: André Breton, Marcel Duchamp, Paul Éluard, Maurice Heine, Pierre Mabille. Reimpresiones: Minotaure (4 volúmenes). (1968). New York: Arno Press; Minotaure (3 volúmenes). (1981). Ginebra: Albert Skira. Hay que destacar dos monografías: GOERG, C. (Ed.). (1987). Regards sur Minotaure. La revue à tête de bête. Ginebra: Musée d'art et d'histoire de Genève / París: Musée d'art moderne de la Ville de Paris; YERSIN, V. (Ed.). (2008). Chants exploratoires: Minotaure, la revue de Albert Skira, 1933-1939. Ginebra: Cabinet des estampes du Musée d'art et d'histoire.

36 CHEVREFILS-DESBIOLLES, Y. (1993). Op. cit., p. 135.

37 Es la opinión más extendida. Sin embargo, Brassaï duda entre Bataille y Masson (BRASSAÏ. (1969). Conversations avec Picasso. París: Gaullimard, p.19), mientras Albert Skira afirma en la introducción a la primera reimpresión de Minotaure (Arno Press) que surgió de Roger Vitrac (YERSIN, V. (2008). Génèse d'un mythe. En YERSIN, V. (Ed.). Op. cit., 16-21, p. 18.) 

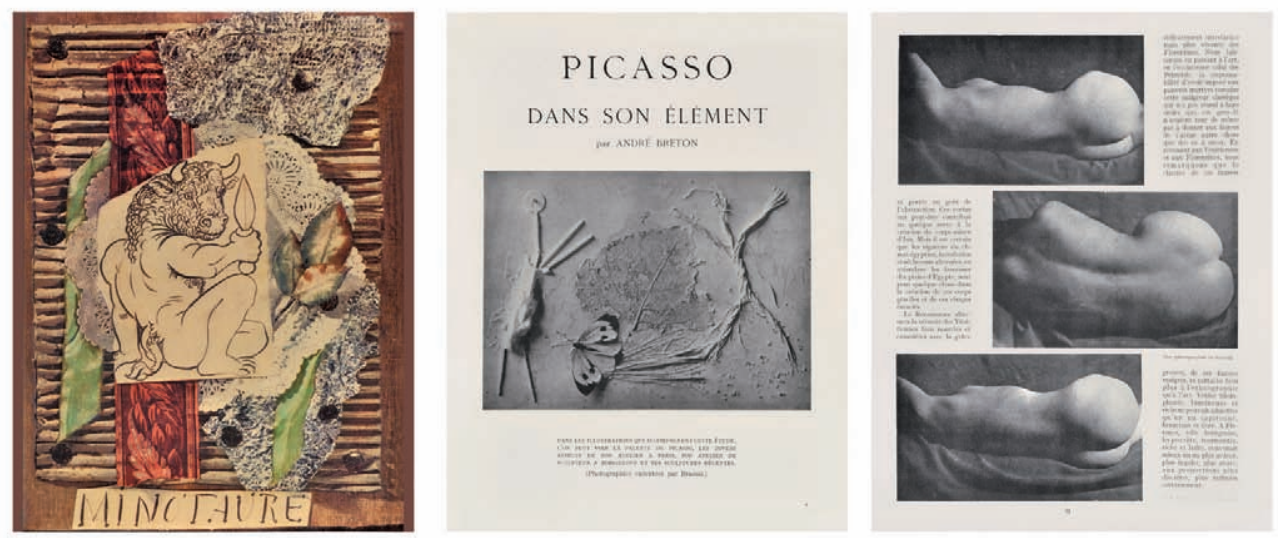

Fig. 6. Minotaure (nota 37): Picasso y el primer número.- a) Cubierta debida a Picasso; b) Pág. inicial del monográfico dedicado a Picasso por A. Breton; c) Variété du corps humain de M. Raynal. Pág. con fotografías de Brassaï.

ción surrealista a través de las ilimitadas posibilidades técnicas y de distribución de la revista de Skira. Pero había un cierto precio: "Breton y Bataille, afirma José Pierre, tendrían licencia para hablar de todo, salvo de sus ideas sociales y políticas. Y la única palabra prohibida sería, sin duda, la que ellos tenían entonces en mayor estima: revolución" 38 . Así, de ser convencidos traidores a su propia clase burguesa en pos de la lucha proletaria, tal como proclamaba Aragon en $L S . A S D L R$, pasaban a ejercer su acción desde y para la burguesía ilustrada moderna. Brassaï, desde su proximidad con los surrealistas, relataba años después cómo se vivió este conflicto dentro del grupo: "Y esta publicación suntuosa, (...) inaccesible a los bolsillos proletarios, solo podía estar dirigida a la despreciable burguesía, a un medio de esnobs titulados y adinerados, primeros mecenas y coleccionistas de obras surrealistas. Aceptar esta colaboración, esta colusión con el 'capitalismo' ¿no era traicionar sus principios, rebajarse? Estas cuestiones fueron ampliamente debatidas antes de aceptar la oferta de Skira y Tériade" 39 . Se elegirá, finalmente, la gran amplificación que Minotaure podía aportar a la revolución surrealista y se deja de lado, pero solo en lo relativo a este medio, su militancia al servicio de la revolución social. Acostumbrado como estaba Breton a ejercer un control del grupo y de sus órganos de difusión en primera persona, ahora sin embargo -tal hubo de ser su interés-, acepta una dirección en la sombra compartida, además, con Tériade, quien sí figura hasta el $\mathrm{n}^{\circ} 9$ como Director artístico de la revista y que representaba una crítica de arte avanzada, pero dentro de una moderni-

38 PIERRE, J. (1987). André Breton et/ou "Minotaure". En Regards sur Minotaure. La revue à tête de bête. Op. cit. (95-119, p. 95). Brassaï alude a este límite: "Si bien en Minotaure podían mantener el espíritu surrealista, debieron renunciar a la combatividad que caracterizó otrora sus revistas... (...) 'bajar a la calle revólver en mano' o ‘entrar en el arte'” (BRASSAÏ. (1969). Op. cit., p.23)

39 BRASSAÏ. (1969). Op. cit., p.23. En la primera parte de este libro (pp. 17-58), Brassaï ofrece un relato detallado de sus vínculos con los surrealistas y de las circunstancias en que se desarrolló Minotaure. 

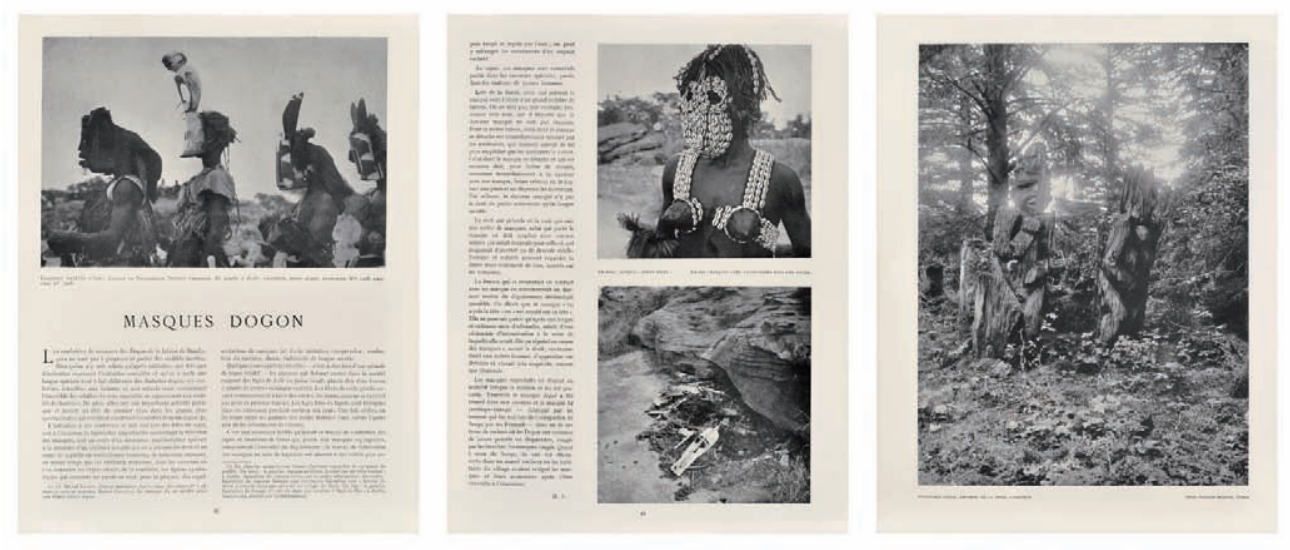

Fig. 7. Minotaure: Etnografía.- a, b) El nº 2: Mission Dakar-Djibouti 1931-1933. Págs. de Masques Dogon. M. Leiris (nota 42) presenta el arte dentro del ritual; c) Entretien avec un Tsimshian de K. Seligmann, $\mathrm{n}^{\mathrm{0}}$ 12-13. Imagen del último artículo etnográfico.

dad continuadora de las renovaciones estético-formales de preguerra, hacia la que los surrealistas habían hecho en más de una ocasión expreso su desprecio. Éluard aporta un significativo testimonio de la situación: "El número 3 de Minotaure puede determinar el logro de nuestros objetivos en esa revista, por ello, Breton y yo le dedicamos todo nuestro tiempo. Breton hace en este sentido un esfuerzo desesperado, ya sabes cómo hay que, sobre todo con Tériade, luchar por cada detalle" 40 .

[Figs. 6, 7.] Minotaure. Revista artística y literaria. Artes plásticas, Poesía, Música, Arquitectura, Etnografía y mitología, Espectáculos, Estudios y observaciones psicoanalíticas. Tal es el encabezamiento de la revista desde el primer número, en cuya declaración de intenciones dice no querer limitarse a la información, en alusión a las revistas de arte, y se compromete a contextualizar su interés por el arte y convertirse en espejo siempre actual de su época. La primera doble entrega de la revista habla ya de esta diversidad y relativiza el predominio de lo perteneciente al concepto "Artes plásticas". Skira quiso impresionar a los 800 suscriptores con que ya contaba lanzando los dos primeros números, en sendos fascículos, simultáneamente. El primero es una miscelánea de asuntos muy característica de la línea que seguirá la publicación pero con el destacado protagonismo de Picasso que crea la portada y a quien se dedica el amplísimo monográfico Picasso dans son élement $\left(\mathrm{n}^{\circ} 1\right.$, junio 1933) de Breton y Brassaï, centrado en el contexto vital de su obra, muy en particular la escultura, que es fotografiada en el taller; se trata del más bello artículo-reportaje confeccionado nunca sobre el artista. Además: Éluard, Reverdy, Masson y su Matanzas, Sade por Maurice Heine, Dalí, Lacan, Kurt Weill, etc. El segundo es un monográfico

40 Paul Éluard en carta a Gala Éluard, septiembre 1933. En CHEVREFILS-DESBIOLLES, Y. (1993). Op. cit., p. 136. 
concebido por el Michel Leiris ${ }^{41}$ sobre la expedición etnográfica por él dirigida, Mission Dakar-Djibuouti que acababa de concluir. Los contrastes entre contenidos de ambos fascículos son extremos y el diálogo resultante complejo y sin conclusiones. Es lo propio de Minotaure, una revista capaz de enviar a grandes audiencias cultas lo corrosivo y lo experimental, lo delirante y lo horrible, una realidad cruda, bella y también científica, envuelta en una irresistible atracción bibliográfica y de una visualidad sin límites que hace indisoluble la relación texto-imagen. Los propios sumarios de esta primera doble entrega, $\mathrm{n}^{\text {os }} 1$ y 2 , y en general la compleja diversidad resuelta en Minotaure, pueden sintetizarse en tres vertientes o procedencias de algún modo ya sugeridas. En primer lugar, la vertiente constituida por la crítica de arte profesional; en segundo lugar, la conformada por gentes muy variadas asociables a los círculos de Bataille en los años de Documents y por el propio referente implícito de esta revista $\mathrm{y}$, en tercer lugar, el surrealismo de LS.ASDLR, que acaba asimilando a sus intereses la experiencia aportada por las otras dos procedencias.

Crítica de arte, documentos de lo real y surrealismo.- Minotaure nunca fue, ni puede confundirse, con una revista de arte, sin embargo, su sistemática dedicación al arte y la presencia de la crítica profesional en ella exige considerar aquel formato como parte de su carga genética. Tériade, asumió desde el primer momento las labores de crítica de arte compartidas, sobre todo, con Maurice Raynal, un histórico de la crítica moderna que había desarrollado un papel equivalente en L'Esprit Nouveau, la revista del Purismo. Aunque el sentido de la crítica artística de Tériade y Raynal no era esencialmente distinto de lo adecuado a Cahiers d'Art, su planteamiento discursivo y formal en Minotaure difiere. Aquí, sus textos se resuelven casi siempre en una sola página que da paso a largas series de imágenes. Tal vez suficiente si se repara en que se aplican casi siempre a cuestiones teóricas, a una cierta filosofía del arte moderno: Emancipation de la peinture ( $\left.\mathrm{n}^{\mathrm{o}} 3-4\right)$, Aspects actuels de l'expression plastique $\left(\mathrm{n}^{\circ} 5\right)$, La peinture surréaliste $\left(\mathrm{n}^{\circ} 8\right)$, Constance du fauvisme $\left(\mathrm{n}^{\circ} 9\right)$; por aludir a títulos de Tériade en los que, en ocasiones, apenas se llega a citar el nombre de un solo artista $^{42}$. Tampoco abunda para el arte moderno el formato monográfico, sin embargo, el más característico de las revistas de arte. El análisis crítico formalista propio de las anteriores décadas cede ante la presencia de artistas del surrealismo, y aquellos críticos de la modernidad asumen rápidamente, aunque no siempre con la misma fortuna, conceptos analíticos derivados de la hermenéutica surrealista. Incluso en la estructura de los artículos, y muy claramente en el uso de la imagen fotográfica, se percibe este deslizamiento que tiende a poner la crítica de arte aparecida en Minotaure al servicio del surrealismo. Este es el caso muy destacado de Dieu-table-cubette ( $\left.\mathrm{n}^{\circ} 3-4\right)$ o de Variété du corps humain $\left(\mathrm{n}^{\mathrm{o}} 1\right)$, sendos artículos de Raynal cuyo texto crítico cede

41 Michel Leiris es sobre todo conocido como etnógrafo, pero perteneció al grupo surrealista inicial, siendo muy activo en su revista $L R S$. Se implicó posteriormente en Documents donde tuvo un papel fundamental al lado de G. Bataille, y participó en Un cadavre.

42 Gwiherm Perthuis pone en valor la aportación crítica de Tériade a quien considera "uno de los principales actores y pensadores" de Minotaure, capaz de condensar en la brevedad de sus textos "conceptos originales para la época", de "sintetizar un pensamiento general sobre el arte" transversal a épocas y culturas. PERTHUIS, G. (2008). Deux regards sur l'art ancien dans Minotaure. Tériade (1933-1936) et les surréalistes (1937-1939). YERSIN, V. (Ed.). Op. cit., (38-43, p. 41). 
ante las célebres fotografías de talleres de escultores o los perturbadores escorzos humanos con que Brassaï los ilustró. Aun siendo evidentes tales adaptaciones, la tensión entre surrealismo y crítica de arte en el seno de Minotaure fue constante generando, como tendremos ocasión de comprobar, entregas más o menos escoradas en uno u otro sentido.

Consideremos ahora la segunda procedencia antes indicada, el entorno batailleano implicado en Minotaure. Resulta interesante valorar que, contra todo pronóstico, nunca se produjo conflagración efectiva entre los de Breton y la línea derivada de los antiguos colaboradores de Documents. Muy al contrario, el surrealismo de Minotaure debe ser considerado como la síntesis de ambas sensibilidades. A ello contribuyó, sin duda, que Bataille dejó pronto el proyecto, en el $n^{\circ} 3-4$, evitándose así enconar el recuerdo de Un cadavre, e incluso choques más recientes, aún muy presente en los prolegómenos del proyecto. "(Bataille y Masson) esos golfos, nuestros peores enemigos" prevenía Éluard en febrero de 1933. Pero su tono se modera notablemente un mes más tarde, seguramente con la mediación de Masson: "Sin embargo, si tomase (Bataille) la iniciativa de una aproximación pública, esto podría arreglarse. Lo deseo" ${ }^{43}$. Bataille no dio tal paso pero tampoco otros que pudieran empeorar la situación arrastrando con él a sus allegados y así, entre su entorno, incluido su inseparable Masson, y el de Breton prevalecieron las muchas sinergias a las que tantos intereses comunes abocaban.

[Fig. 7.] Minotaure, tanto en su dimensión gráfico-textual como en la diversidad total y perturbadora de contenidos, o su gusto por situarse en los límites de lo aceptable, hallará en Documents el referente más inmediato. En aquella, la revista de cubiertas amarillas, la reconsideración de lo real pone su máxima confianza en la imagen que deviene documento heteróclito hasta el absurdo e intenso hasta el desgarro, conformando una forma superior de discurso, un "montaje figurativo" ${ }^{4}$, practicado con un refinamiento, variedad y efectividad hasta entonces desconocidos, que será íntegramente heredado y perfeccionado para el surrealismo en Minotaure. Sorprende, dado el alcance comercial y el público natural de la revista de Skira, que el corrosivo discurso de Documents perviva incluso en asuntos tan batailleanos como el erotismo asociado a la crueldad y lo sacrificial, sin ahorrar, llegado el caso, lo horrible y explícitamente repugnante. También, desde otros puntos de vista, se percibe una continuidad respecto a Documents, así en la etnografía, donde Minotaure cuenta con hitos como el citado $\mathrm{n}^{\circ} 2$ (junio 1933) de la revista, Mission Dakar-Djibouti 1931-1933, cuyos ingentes documentos etnográficos, antropológicos, musicales o lingüísticos, situaban los artefactos estudiados en su valor de uso, ritual o meramente utilitario, ajenos a adscripciones artísticas, tal como ya se había exigido desde Documents. Y, al igual que en esa revista, hallamos en Minotaure un cientifismo perturbador y antipositivista donde la observación científica supera toda fantasía literaria, como ocurre en los estudios propuestos por Roger Caillois que, sin pertenecer a Documents sufrirá una fuerte influencia de Bataille.

43 PIERRE, J. (1987). Op. cit., p. 98.

44 Se trata de conceptos establecidos por Didi-Huberman para quien Documents constituiría un "museo de la diferencia (de l'écart)", "una contra-historia del arte”. DIDI-HUBERMAN, G. (1995). Op. cit., pp. 14-15. 
[Fig. 6 c.] Respecto a la tercera procedencia indicada, la correspondiente al grupo surrealista y Breton, se puede decir que la revista les perteneció en tal proporción que es su tendencia la que caracteriza sus contenidos y su imagen. Como se ha ido viendo, crítica profesional de arte y entorno de Documents se integran en el conjunto surrealista propuesto, aunque con metodologías diferenciadas. Al margen de sus contenidos textuales los artículos de Raynal ilustrados por Brassaï antes citados, entran de lleno en el plan surrealista, o bien, cuando este mismo crítico propone Réalité et mythologie des Cranach ( $\left.\mathrm{n}^{\circ} 11\right)$ ilustrado por 8 páginas con los desnudos femeninos de los Cranach -verdadera belleza convulsiva, como en otros artistas renacentistas y románticos traídos a la revista-, Breton ve cumplido un objetivo ${ }^{45}$. Exactamente igual, cuando Tériade presenta Émancipation de la Peinture o La peinture surrealiste, por ejemplo, sus amplias selecciones de imágenes de arte, en gran parte netamente surrealistas, cubren otro ámbito fundamental en ese momento del surrealismo. Respecto a la herencia de Bataille y su revista, el proceso no es tanto de aprovechamiento positivo como en el caso de la crítica, como de asimilación mutua hasta una completa síntesis. Según José Pierre "Breton en primer lugar, pero también Dalí seguidos exclusivamente por Éluard y por Péret, van a subvertir total y ostentosamente las técnicas de Documents para ponerlas al servicio, no de un 'izquierdismo' vehemente, sarcástico y cruel, sino de la causa surrealista llevada al más alto grado de exigencia lírica"46.

El intenso primer año de Minotaure.- Aunque solo dos de las entregas de $M i$ notaure ciñen sus contenidos a temáticas específicas: el etnográfico $\mathrm{n}^{\circ} 2$ ya citado $\mathrm{y}$ el $\mathrm{n}^{\circ} 7$ centrado en la noche, todas ellas están fuertemente caracterizadas, tienen un aire distintivo desde su misma portada, diseñada en cada ocasión por un artista, como también por el balance de sus contenidos y su visualidad. Esta circunstancia, unida a su dilatado período de publicación, obliga a una consideración más pormenorizada y cronológicamente contextualizada de cada entrega, que la ponga en relación con las circunstancias y discursos del grupo en cada momento. Por otra parte, aunque Minotaure fue referente y continuidad para la publicación periódica surrealista de los años 30, dejó largos periodos entre entregas y también intereses que no podía atender, como los políticos. Estos huecos fueron en ocasiones ocupados por otros proyectos editoriales periódicos, suerte de interludios que irán apareciendo a lo largo de las siguientes páginas intercalados en el continuo de la revista de Skira.

El primer año de Minotaure, identificable como $1^{\mathrm{a}}$ serie, se ajusta con sus cinco números distribuidos entre junio de 1933 y mayo de 1934, a lo comprometido ante los suscriptores. Es por lo tanto el más intenso y, desde luego, el único en que tal compromiso se cumpla. Aunque desde el $\mathrm{n}^{\mathrm{o}} 6$ se anuncie sistemáticamente que la revista sale cuatro veces por año, los números restantes se irán distanciando hasta la periodicidad de hecho anual de las tres entregas que componen la $3^{\mathrm{a}} \mathrm{y}$ última serie. Este intenso primer año de Minotaure que se iniciaba con los números arriba breve-

45 Sobre los estrechos vínculos y procesos de retroalimentación establecidos entre surrealismo y arte antiguo (y su reinterpretación contemporánea) en Minotaure, trata el texto ya citado de G. Perthuis. PERTHUIS, G. (2008). Op. cit. (38-43)

46 PIERRE, J. (1987). Op. cit., p. 100. 

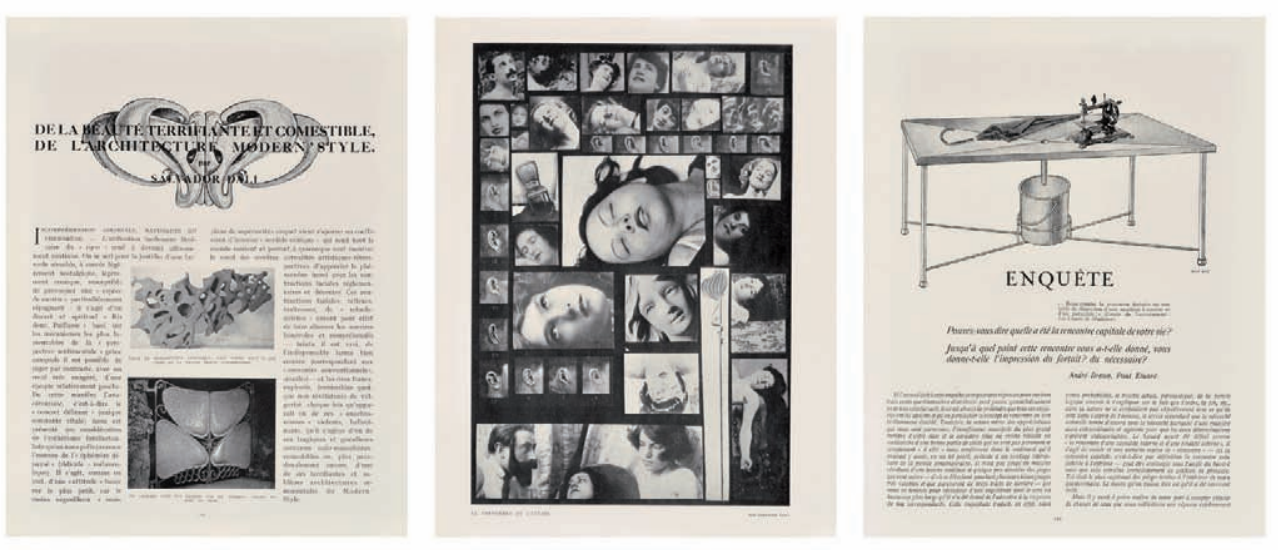

Fig. 8. Minotaure: Surrealismo en el no 3-4.- a, b) De la Beauté terrifiante et comestible, de l'architecture Modern style y fotomontaje de Le phénomène de l'extase de S. Dalí; c) Pág. inicial de Enquête con ilustración de Man Ray, propuesta de Breton y Éluard acerca del azar.

mente comentados, culmina con dos entregas de una densidad asombrosa y, aunque con portadas confiadas a Derain ( $n^{\circ} 3-4$, diciembre 1933) y Bores, (nº 5, mayo 1934), intensamente surrealistas. Una surrealidad puesta en página recogiendo la ya larga herencia editorial del grupo, pero centuplicando su efectividad con el modo de integrar la imagen, que ilustra tanto al texto, como este a ella. Au Paradis des Fantômes ( ${ }^{\circ}$ 3-4), es, por así decir, un estándar del surrealismo, Benjamin Péret relata en él una imaginaria reunión de autómatas y sus creadores que ilustra con perturbadoras imágenes de máquinas parahumanas. En D’un certain Automatisme du Goùt (nº 3-4) Tristan Tzara halla en los modelos de sombrerería femenina del momento, debidamente fotografiados por Man Ray, manifestaciones involuntarias de formas sexuales que opone a la higiene formal moderna.

[Fig. 8 a, b.] Sobre formas simbólicamente desplazadas habla igualmente un artículo memorable: De la Beauté terrifiante et comestible, de l'architecture Modern style $\left(\mathrm{n}^{\mathrm{o}} 3-4\right)$, ilustrado por Brassaï, que documenta el Modern style parisino, y por Man Ray, que viaja a Barcelona para fotografiar la obra de Gaudí. Una página introductoria lo presenta: Sculptures involontaires, con imágenes de Brassaï, y una suerte de epílogo, que es realmente otro artículo, cierra el conjunto: Le phénomène de l'extase ilustrado con un montaje de imágenes extraídas de la pornografía, el arte o la policía compuesto por Dalí ${ }^{47}$. Se trata de dos de los ocho artículos aportados por Salvador Dalí a la revista en los que aprovecha, como tal vez ningún otro componente del grupo, los recursos puestos a su alcance, creando artículos que son per se propuestas

47 DALÍ, S. (1933, diciembre) Sculptures involontaires. Minotaure, 3-4, 68; De la Beauté terrifiante et comestible, de l'architecture Modern'style. Minotaure, 3-4, 69-76; Le phénomène de l'extase. Minotaure, 3-4, 76-77. Dalí propuso a Brassaï y a Man Ray los objetos a fotografiar para ilustrar sus textos, incluso los objetos de producción automática de Sculptures involontaires; BRASSAÏ. (1969). Op. cit., pp. 54-55. 

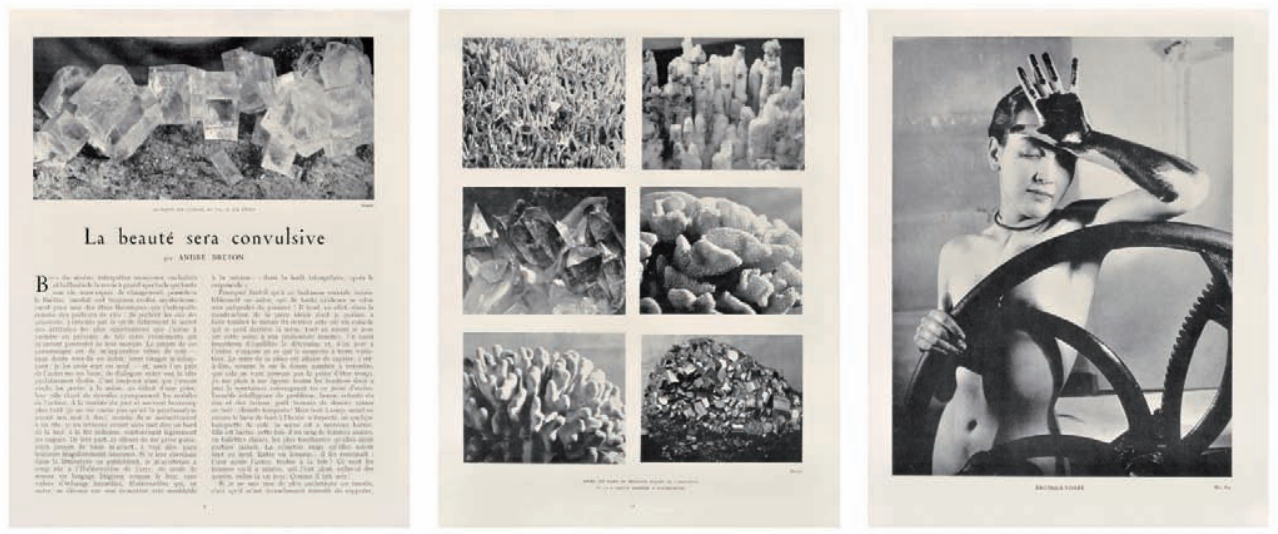

Fig. 9. Minotaure: André Breton. La beauté sera convulsive, ${ }^{\circ} 5$ (nota 45)- a) Pág. inicial del artículo; b) Imágenes del mundo natural, de Brassaï; c) Méret Oppenheim por Man Ray en Érotique-voilée.

artísticas. Su disolución de la modernidad racionalista sirviéndose de Gaudí y de las rejerías Modern style del metro parisino o de la equiparación de éxtasis de muy diversa procedencia, son hitos de la cultura surrealista; como, en realidad, toda su extraordinaria participación en Minotaure, con colaboraciones escritas en todos los números de las dos primeras series y siendo con diferencia el artista más reproducido en la revista. Les nouvelles couleurs du sex appeal spectral $\left(\mathrm{n}^{\circ} 5\right)$ continúa la serie daliniana con un "análisis espectral del fantasma y del espectro" suerte de teoría acerca de lo corpóreo y lo virtual o "extra-fino". Página con página La mante religieuse $\left(n^{\circ} 5\right)$ abre el ciclo de colaboraciones de Roger Caillois, con un artículo que pone en contacto biología y psicoanálisis, de nuevo un referente de la revista. Acto seguido, a contrapágina, Man Ray, que ilustraba con alusiones al Balzac de Rodin la teoría espectral daliniana, da muestra en Danses-horizons $\left(\mathrm{n}^{\circ} 5\right)$ de una pasión por lo femenino constantemente renovada en la revista con sus fotografías.

[Figs. 8 c, 9, 21 a.] La maison de Mozart de Victorien Sardou, dibujos de videntes, pinturas y grafías automáticas de Hélène Smith, Le palais Idéal de Le Facteur Cheval son algunas de las muchas imágenes dignas realmente de aquel "ojo salvaje", ojo en estado primitivo de Le surréalisme et la peinture ${ }^{48}$, que ilustran Le message automatique $\left(\mathrm{n}^{\mathrm{o}} 3-4\right)$. Breton inicia así su programa propiamente surrealista, aduciendo decididamente la imagen a sus textos e iniciando una serie de contribuciones sobre la acción involuntaria en la actividad artística que contrapesaran en el arte la arrolladora influencia estilística de la retórica daliniana hasta eliminarla por completo hacia el final de la década. "La belleza convulsiva será erótico-velada, explosiva-fija, mágica-

48 "El ojo existe en su estado primitivo. Las maravillas de la tierra a trescientos metros de altura, las maravillas del mar a trescientos metros de profundidad, tienen por testigo al ojo salvaje". BRETON, A. (1925, julio). Le surréalisme et la peinture. La Révolution surréaliste, 4, p. 26. 
circunstancial o no será" ${ }^{49}$, concluye el texto de La beauté sera convulsive ( $\left.{ }^{0} 5\right)$, la siguiente propuesta de Breton que interactúa con fabulosas imágenes cristalográficas de Brassaï y otras de Man Ray como la célebre de Méeret Oppenheim, de nuevo la mujer, entintada junto al volante del tórculo: Érotique-voillée. La importancia de este artículo en la obra poética de Breton es fundamental como inicio de otro ciclo al que después se prestará atención. También Breton, junto a Éluard, firma Enquête (n ${ }^{\circ}$ 3-4), única propuesta de este tipo, y de tan larga tradición en el grupo, aparecida en Minotaure, que acentúa la ya indicada integridad surrealista de estas entregas. Bajo una representación del bello, azaroso y paradigmático encuentro imaginado por Lautreamont y con la convicción extraída de la ciencia moderna de que "el azar sería la forma de manifestarse de la necesidad exterior que se abre camino en el inconsciente humano”, se lanzan las preguntas: “¿Puede decir cuál ha sido el encuentro capital de su vida? ¿Hasta qué punto ese encuentro le ha dado, le da, la impresión de fortuito, o bien, de necesario?". Ciento cuarenta respuestas vienen a continuación ${ }^{50}$.

\section{Primer interludio: Documents 34. Interventions surréalistes}

[Fig. 10 a.] La inevitable toma de partido de 1934.- El $\mathrm{n}^{\circ} 5$ de Minotaure se imprimía en mayo de 1934, estaba, por lo tanto, completamente confeccionado cuando el 20 de marzo el surrealista bruselense E. L. T. Mesens -quien facilitó la edición de Viollet Nozière- le ofrece a Breton un número de su revista Documents $34^{51}$; hasta diciembre de ese mismo año no se imprimirá el $\mathrm{n}^{\mathrm{o}} 6$ de Minotaure correspondiente al invierno de 1935. Desde un punto de vista editorial -se acababa de entregar un número de Minotaure- la ocasión que se le presenta a Breton y su grupo es tan oportuna como la que en 1929 se les ofreció desde Variétés, pero desde un punto de vista político, en plena metástasis del fascismo en Europa, se hacía más acuciante que en aquel año disponer de un "medio de intervención" que solventase el veto político de Minotaure. En tales circunstancias, Mesens ofrece a Breton llevar a cabo en Documents 34 una experiencia "equivalente para este año de lo que fue 'Le surréalisme

49 BRETON, A. (1934, mayo). La beauté sera convulsive. Minotaure, 5, 8-16, p.16

50 BRETON, A. y ÉLUARD, P. (1933, diciembre). Enquête. Minotaure, 3-4, 101-116, pp. 101-102. Con esta se cierra una serie de cinco Enquêtes comenzada en la época de Littérature. Frente a la Recherche, circunscrita al grupo (a pesar de los intentos de Artaud), la Enquête se abría al público y lograba extender más allá del grupo su campo de intereses. "Puede considerarse la encuesta surrealista, al mismo tiempo, como una provocación y una confrontación, como una botella lanzada al mar y un cartel publicitario, (...) Al someter una preocupación surrealista a los no iniciados, se la pone a prueba". SEBBAG, G. (2004). De 1'enquête surréaliste. En SEBBAG, G. (Ed.). Enquêtes surréalistes (168-172, p.171). París: Jean-Michel Place.

51 La cabecera belga Documents -que nada tiene que ver con la revista de G. Bataille- se hacía acompañar cada año de las dos últimas cifras del mismo. Fundada en 1933, Documents 33 era una revista mensual caracterizada por su dedicación cinematográfica, "Cine - Crítica literaria, artística y social" era su subtítulo que indica el interés de vincular cine y estética. Su línea y formato atrajo rápidamente al entorno surrealista bruselense y al año siguiente de su aparición Documents 34 queda bajo la dirección de E. L. T. Mesens, animador del surrealismo y relacionado con Variétés, que da un giro a la revista convirtiéndola en el organismo del grupo belga: Nougé, Magritte, Souris, Scutenaire y él mismo. 

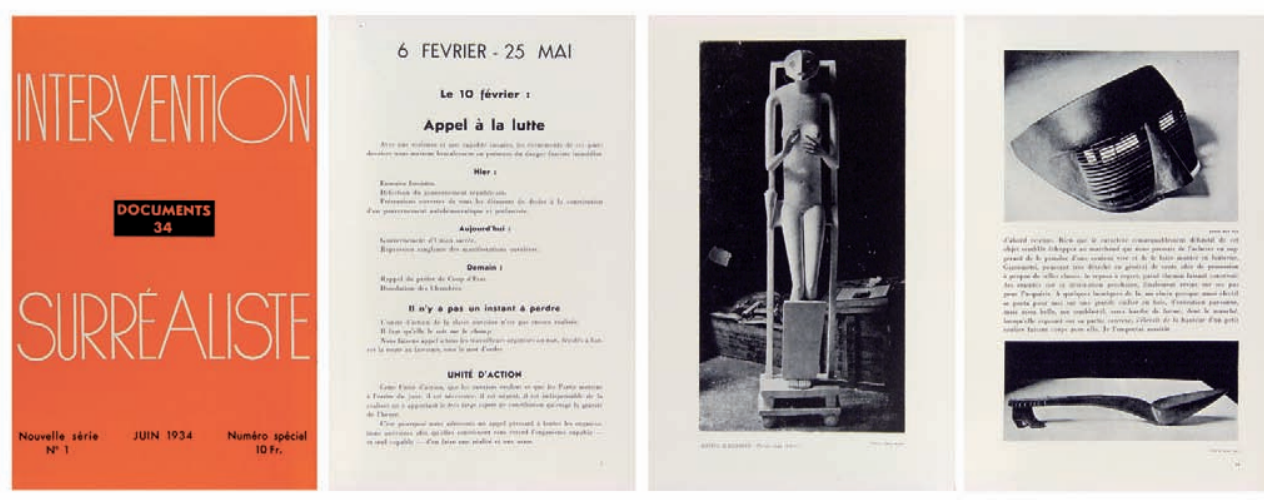

Fig. 10. Documents 34. Intervention surréaliste (nota 47).- a) Cubierta, junio 1934; b) Primera de las páginas alusivas a la asonada fascista de 1934; c, d) Artículo Equation de l'objet trouvé de Breton: L’objet invisible de Giacometti y pág. con objetos encontrados.

en 1929' de Variétés" ${ }^{52}$. El recuerdo de aquel número surrealista de Variétés es, efectivamente, inevitable al considerar el de Documents 34: el mismo formato en cuarto y abundancia de ilustración, la participación del grupo belga, y la implicación en el momento histórico. El de 1934 es muy grave, corresponde al levantamiento -putch fasciste- que el 6 de febrero de 1934 protagonizan las Ligas de la derecha contra la Assemblée Nationale, y las primeras respuestas de las izquierdas que preconizan ya el Front Populaire.

[Fig. 10 b] En junio sale el número surrealista de Documents 34. Su título: Interventions Surréalistes, alude a una acción poética y política efectiva; pero de la política directa del manifiesto y de la firma comprometida. Ya no se trata como en el Second manifeste o su precedente $\grave{A}$ suivre ${ }^{53}$, de establecer el encaje social natural y necesario para un surrealismo revolucionario, sino de tomar partido y ejercer una acción urgente acerca de acontecimientos inmediatos. René Magritte, E. L. T. Mesens, Paul Nougé, Jean Scuetenaire y André Souris, representantes del grupo belga, abren con L'action immediate, una proclama de carácter doméstico acerca de sus dificultades con el Partido comunista. Los de París, sin embargo, tienen preocupaciones más acuciantes: el mismo 10 de febrero ellos habían tomado la iniciativa lanzando un panfleto que convocaba a la unidad de los intelectuales: Appel à la lutte y poco después Breton se entrevistaba con el líder socialista Leon Blum para pedirle igualmente su apoyo. 6 Fevrier - 25 Mai es la segunda entrada que se limita a transcribir, incluso

52 MASSONET, S. (1998). "Intervention surréaliste” ou la invention du surréalisme belge. En Documents 34. Intervention surréaliste (Reimpresión) (Introducción, 4-21, p. 17, nota 3). Bruselas: Didier Devillez. Variétés fue una revista bruselense de información general pero muy interesada por la cultura de vanguardia. En 1929 cede un fascículo al grupo liderado por Breton, que es al que aquí se hace referencia.

53 À suivre, recoge un debate abierto a amplios círculos intelectuales acerca de la posibilidad de unir fuerzas en aras de una acción revolucionaria común. ARAGON, L. y BRETON, A. (1929, junio). À suivre. Variétés. Le surréalisme en 1929. Bruselas. 
tipográficamente, una serie de panfletos de acción política firmados y lanzados por el grupo entre tales fechas, con el fin de sumar fuerzas para prevenir el "peligro fascista" manifestado en Francia el 6 de febrero. Los surrealistas proclaman así netamente sus prioridades antes de dar paso a asuntos más abstractos, pero las alusiones antifascistas recorren aquí y allá Documents 34 que finaliza con Réflexions conduisant à préciser la signification antifasciste du surréalisme, el texto más conocido de Pierre Yoyotte que, al igual que su hermana Simone Yoyotte -ambos originarios de Martinica y únicos miembros negros del grupo de París-, había publicado previamente en $L S . A S D L R$. Todas las contradicciones irresueltas surgidas entre el "gran deseo" surrealista, y la dinámica revolucionaria basada en el materialismo dialéctico y la lucha de clases, se manifiestan: "Los surrealistas no son obreros, no tienen necesidad de disimular serlo, pueden rendir sus servicios siendo quienes son; han nacido en la burguesía (...) Ante la carencia más o menos general, la actitud de los surrealistas y de algunos otros, se sitúa al inicio de lo que debe ser hecho" ${ }^{54}$. El fascismo, según Yoyotte, recurre a la exacerbación del sentimiento, que es lo propio de la juventud, frente a ello, la libertad, y por lo tanto la revolución, es recuperar el deseo no reprimido asociado a la infancia.

[Fig. 10 c, d.] La espontaneidad de nuevo.- Sirvan estos apuntes para ilustrar la persistencia de lo político en el grupo surrealista y cómo tal interés se desarrolla al tiempo que la gran aventura estética de Minotaure. Pero, en definitiva, lo que otorga a Documents 34 Intervention surréaliste un auténtico estado de gracia son sus contenidos artístico-literarios intensificados por el conflicto social que los enmarca, que recuperan el tono sobrio e intenso de $L S . A S D L R$. Su importante carga gráfica está dedicada casi por completo a la reproducción de obras surrealistas. Por ejemplo, de artistas muy recientemente adscritos al grupo: Balthus (La rue), Méret Oppenheim o Victor Brauner. Junto a ellos, Breton muestra su faceta artística como pocas veces: los collages al estilo de La femme 100 têtes o su Communication relative au hasard objectif; Marcel Duchamp sitúa Moustiques domestiques demi stock en contra-página del texto de Dalí Derniers modes d'excitation intellectuelle pour l'été de 1934 del que extraigo dos breves definiciones: "Pintura: 'Fotografia' a mano y en color de la 'irracionalidad concreta' y del mundo imaginativo en general. / Escultura: Molde hecho a mano de la "irracionalidad concreta' y del mundo imaginativo en general" ${ }^{5}$. Tanguy dibuja sobre las páginas de un diccionario en En marge des mots croisés, mientras Roger Caillois desarrolla su posición sobre las metodologías surrealistas en Systématisation et détermination. Lo hace entre pinturas de Valentine Hugo y René Magritte, pintor este último que, junto a los escritores ya citados, representa la importante participación del grupo belga. La plenitud surrealista que implican las investigaciones colectivas está presente en Le dialogue en 1934: “-¿Qué es el arte? -Es una

54 YOYOTTE, P. (1934, junio). Réflexions conduisant à préciser la signification antifasciste du surréalisme. Documents 34. Intervention surréaliste, 1, 86-91, pp. 90-91.

55 DALÍ, S. (1934, junio). Derniers modes de excitatión intellectuelle pour l'été 1934. Documents 34. Intervention surréaliste 1, 33-35, p. 34. 
concha blanca en una palangana de agua" ${ }^{56}$, responde Giacometti a Breton, definición mantenida en el Dictionnaire abrégé du surréalisme (1938). Ambos, igualmente, recorren el Marché aux puces en busca de objetos reveladores, tal como relata el poeta en Equation de l'objet trouvé, uno de sus mejores textos sobre el azar objetivo, que se abre con la fotografía de Dora Maar de L'objet invisible de Giacometti, titulado aquí Personnage fémenin. Una espontaneidad que recuerda otros momentos editoriales del grupo se hace también manifiesta en la renovada carga poética de las páginas de Documents 34: Una personalidad siempre nueva, siempre diferente, el amor de sexos confundidos en su contradicción, surge sin cesar de la perfección de mis deseos. Toda idea de posesión le es forzosamente extraña, titula Eluard un también extenso poema ilustrado. Maurice Heine, poeta en esta ocasión, ensalza a un Sade revolucionario, además Péret, Tzara, Crevel, Hugnet, etc.

\section{Minotaure 1935, la poesía. Contre-attaque, el antifascismo}

[Fig. 11 a, b.] Minotaure en 1935.- Sin solución de continuidad, tras el intenso paréntesis de Documents 34, en diciembre del mismo año está ya impreso el $\mathrm{n}^{\circ} 6 \mathrm{de}$ Minotaure que inaugura el $2^{\circ}$ año y serie de la publicación. Tériade lo presenta como "un terreno de colaboración entre los elementos más agudos e importantes de generaciones diferentes" y justifica el lujo de la revista "como una necesidad orgánica" 57 . Marcel Duchamp firma su portada y Breton traza un monográfico de la obra del artista en Phare de La Mariée. Entre las páginas de esta entrega algunos iconos del arte surrealista, como la carta de presentación de Hans Bellmer, el indescriptible pliego Poupée. Variations sur le montage d'une mineure articulée que, acto seguido, da paso a Apparitions aérodynamiques des "Êtres-Objets", uno de esos artículos de Dalí que cuentan tanto con el texto, como con la imagen. Por lo demás, tal como anunciaba Tériade, variedad generacional e intelectual: Ambroise Vollard, Valéry, Saint-Exupéry, Élie Faure, entre otros, escriben en un fascículo de contenidos muy abiertos, que concluye con un cuadernillo en páginas diferenciadas en verde dedicado a una poesía a la que pareciera le cuesta encontrar su lugar literario en las páginas de una revista asaltada de estímulos dispares y marcadamente visual. El estudio de Breton La grande actualité poétique lo encabeza, para dar paso a una selección de poemas de Jouve, Péret, Éluard y del propio Breton; pero precedidos por una página completa de textos del último descubrimiento surrealista, Gisèle Prassinos, una poeta de 14 años. "Alicia II", como fue saludada por Éluard. Con los años aquella recordaba escépticamente su estatus surrealista: "yo ilustraba su teoría, era una prueba de que el inconsciente existe y puede funcionar"

56 BRETON, A. et al. (1934, junio). Le dialogue en 1934. Documents 34. Intervention surréaliste 1, $24-$ 25 , p. 25.

57 TÉRIADE, E. (1934, diciembre). Página de presentación sin numerar. Minotaure, 6.

58 DRUET, S. Gisèle Prassinos : d'Alice II à la reconquête de l'esprit d'enfance. Recuperado de http:// litur.free.fr/112.htm 

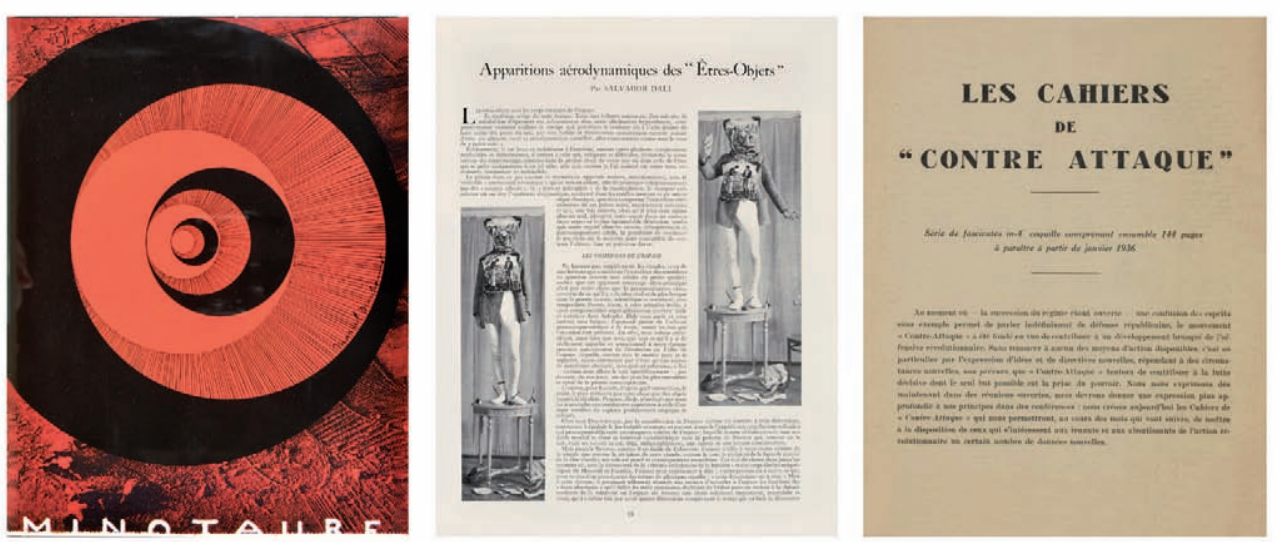

Fig. 11. 1935, poesía y antifascismo.- a, b) Minotaure $n^{\circ}$ 6: Cubierta de M. Duchamp y página inicial de Apparitions aérodynamiques des "Êtres-Objets", de S. Dalí; c) Primer número de Les cahiers de "Contre-attaque", plataforma de unión de intelectuales antifascistas.

[Fig. 12.] La disparidad de ese $n^{\circ} 6$, da paso en junio de 1935 a uno de los fascículos más armoniosos, visuales y surrealistas de la serie, el $\mathrm{n}^{\circ} 7$ subtitulado Le côté nocturne de la nature, con cubierta de Miró. Una obra nocturna de Georges de La Tour seguida de grandes fotografías de Man Ray en las que se materializa la analogía surrealista mujer-noche, dan paso al deslumbrante e igualmente nocturno, en cuanto a la confusión primordial de que trata, Mimétisme et psychasthénie légendaire, uno de los más influyentes textos de Caillois presentado con imágenes científicas que anclan surrealismo y realidad. Como también lo hace Oiseaux de nuit. Chouettes et hiboux de Jacques Delamain, centrado en tales rapaces nocturnas, cuyos ojos miran fijamente a lo largo del artículo; de nuevo el texto y la imagen científicos al servicio del surrealismo. "El día no ha recibido aún del hombre el privilegio del eclipse. Ese poder que tiene la noche de iluminarse de un día eléctrico"59; las iluminaciones de la noche percibidas a través de las vistas nocturnas de París captadas por Brassaï e ilustradas con poemas de las Noches de Edward Young -Le jour est trop court- ocupan sin duda el corazón del fascículo. Al margen de estas fotografías o de las citadas de Man Ray, el arte surrealista no mantiene ni en este ni en el anterior número una presencia destacada, con excepciones como el pliego Illustrations pour "Wuthering heights" de Balthus o como la apropiación definitiva para el arte surrealista que supone Paolo Uccello, peintre lunaire de Georges Pudelko. Surrealismo quintaesenciado es igualmente el que en aquellos años Breton reserva de su pluma para Minotaure, construyendo, artículo a artículo, una fenomenología del amor como azar objetivo, con las calles de la ciudad y Jacqueline Lamba, su reciente esposa, como catalizador. Les Halles, la Tour Saint-Jacques, ilustran La nuit du Tournesol, relato de derivas,

59 BRASSAÏ. (1935, junio). Paris a sept collines aussi, où sont-elles dans la nuit? Minotaure, 7, 70-71, p.70. 

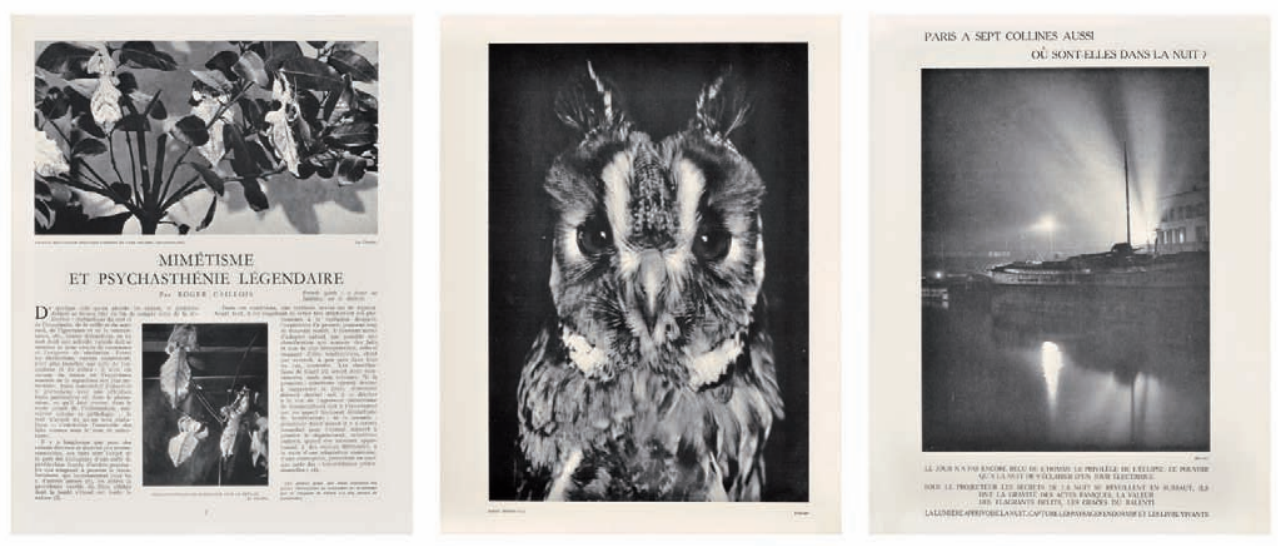

Fig. 12. Minotaure $\mathrm{n}^{0}$ 7: Le côté nocturne de la nature.- a) Pág. inicial de Mimétisme et psychasthénie légendaire, de R. Caillois; b) Imagen de Oiseaux de nuit. Chouettes et hiboux, de J. Delamain; c) Una de las fotografías nocturnas de Brassaï, incluidas en la entrega.

confluencias y premoniciones en la noche de París que continúa lo comenzado en La beauté sera convulsive ( $\left.\mathrm{n}^{\circ} 5\right)$.

Bofetadas y rencuentros: contra el fascismo.- Pero exactamente al mismo tiempo que se confeccionaba este $\mathrm{n}^{\mathrm{0}} 7$, hasta aquí tan incompletamente descrito y que hay que considerar como obra destacada del surrealismo colectivo, otros acontecimientos reclamaban igualmente la atención del grupo. Breton mantiene una importante actividad política, en abril lee en Praga la conferencia Position politique de l'art d'aujourd'hui: "Todos sus actos [del hombre, en el contexto: del intelectual] están sometidos a juicio, no ante su conciencia, sino ante la conciencia colectiva de cuantos quieren terminar con un monstruoso sistema de esclavitud y de hambre" ${ }^{60}$. A pesar de los graves desencuentros ya relatados, el grupo trabaja en su participación en el Congrès des écrivains pour la defense de la culture, organizado por el PCF para junio de 1935 y al que tenía que acudir Breton en representación de los surrealistas. Sin embargo, días antes, Breton se tropieza en la calle con Ilya Ehrenbourg, delegado soviético en el Congreso que había publicado ofensivas calumnias sobre los surrealistas, y lo abofetea. Su participación es anulada. René Crevel que se había implicado intensamente en el proyecto, se suicida, en honor a lo cual se permitirá finalmente a Éluard leer la ponencia de Breton. Acto seguido este redacta Du temps que les surréalistes avaient raison (8/1935), nuevo tract firmado por el grupo al completo que notifica su ruptura con "Ese régimen, ese jefe, hacia el cual solo podemos manifestar

60 BRETON, A. (1992). Position politique de l'art d'aujourd'hui. En BRETON, A. (Ed. M. Bonnet et alt.). Op. cit., (416-444, p. 416). Esta conferencia quedó integrada en Position politique du surréalisme, el libro de noviembre de 1935 que, según M. Bonnet, marca la ruptura definitiva con el PCF "tras una decena de años de atracción y rechazos, de combates y de esfuerzos por hallar una conciliación con las posiciones políticas y sociales del partido que Breton y sus amigos afirmaban compartir". BONNET, M. (1992) Commentaire a Position politique du surréalisme. En Ibídem, p. 1562. 
formalmente nuestra desconfianza" ${ }^{1}$, alusión a la URSS de Stalin que cierra rotundamente el panfleto.

[Fig. 11 c.] La necesidad de plataformas independientes de acción que oponer al fascismo da lugar a iniciativas como la que propiciará el rencuentro entre Breton y Bataille. Aunque con mayor protagonismo del segundo, ambos crean ese mismo mes de octubre el grupo Contre-attaque como convergencia de intelectuales, marxistas o no, en la lucha anticapitalista y antinacionalista: Contre-attaque. Union de lutte des intellectuels revolutionaires se titula el panfleto inicial que "exige una innegociable dictadura del pueblo armado" más allá de la pusilanimidad revolucionaria del Front Populaire. Les Cahiers de "contra-attaque" dan forma periódica al movimiento sacando un primer número en noviembre donde Breton y Batille se asocian en la firma de algunas entradas al igual que otros surrealistas como Heine o Péret. El tono filosófico y político es absolutamente radical. Tras varias proclamas más y un segundo y último número del boletín, el grupo se disuelve en marzo de 1936, según los surrealistas por la aparición en su seno de tendencias surfascistes. Pero Bataille ya no volverá a ser aquel irreconciliable de Un cadavre como demuestra su colaboración de ese mismo año en Minotaure.

\section{Segundo interludio: Cahiers d'Art: revista de arte surrealista}

[Fig. 13 a.] La modernidad convertida.- Sobre tal implicación máxima en su presente histórico hay que situar los proyectos editoriales en los que se ocuparán los surrealistas durante el año que medió entre la salida del $\mathrm{n}^{\circ} 7$ de Minotaure, en junio de 1935 y la del no 8, en el mismo mes de 1936. De nuevo se les ofrecen las páginas de otra publicación aunque de manera más condicionada que en Documents 34, pues la revista que se interesa por ellos es Cahiers $d^{\prime} A r t^{62}$, la gran revista del arte moderno ante la que, precisamente, se planteaba la competencia en los inicios de Minotaure. Si la condición en esta última era obviar la política, la condición en aquella atenderá a no dejar de ser una revista de arte. Por lo demás, Cahiers d'Art se entrega de facto a la dirección de André Breton y a la colaboración de los surrealistas al completo, dando con ello lugar al episodio editorial más específicamente artístico del grupo y directamente relacionado con su actividad expositiva. Y lo hace nada menos que con dos o, según se mire, tres fascículos consecutivos, correspondientes a ocho números, desde mayo de 1935 hasta febrero de 1936, cerca, pues, de los diez números correspondientes a la suscripción de un año de la revista.

En este aterrizaje surrealista en el medio del arte moderno por excelencia, sorprende, no tanto el deslizamiento hacia lo estético del grupo de Breton, como la

61 BRETON, A. (1992). Du temps que les surréalistes avaient raison. Ibid., (460-471, p. 471). Se trata de un texto igualmente integrado en Position politique du surréalisme.

62 Cahiers d'Art. Subtítulo hacia 1930: Revue d'art paraissant dix fois par an. Peinture, sculpture, architecture, art ancien, ethnologie, cinéma. Editada en París entre 1926 y 1960. Formato: 25 x $31 \mathrm{~cm}$. Editor y director Chistian Zervos. Sin reimpresiones ni recopilaciones. Sí existe, un índice exhaustivo: VALLIER, D. (1981). Index Général de la revue “Cahiers d'Art” 1926-1960. París: Editions Cahiers d'Art. 

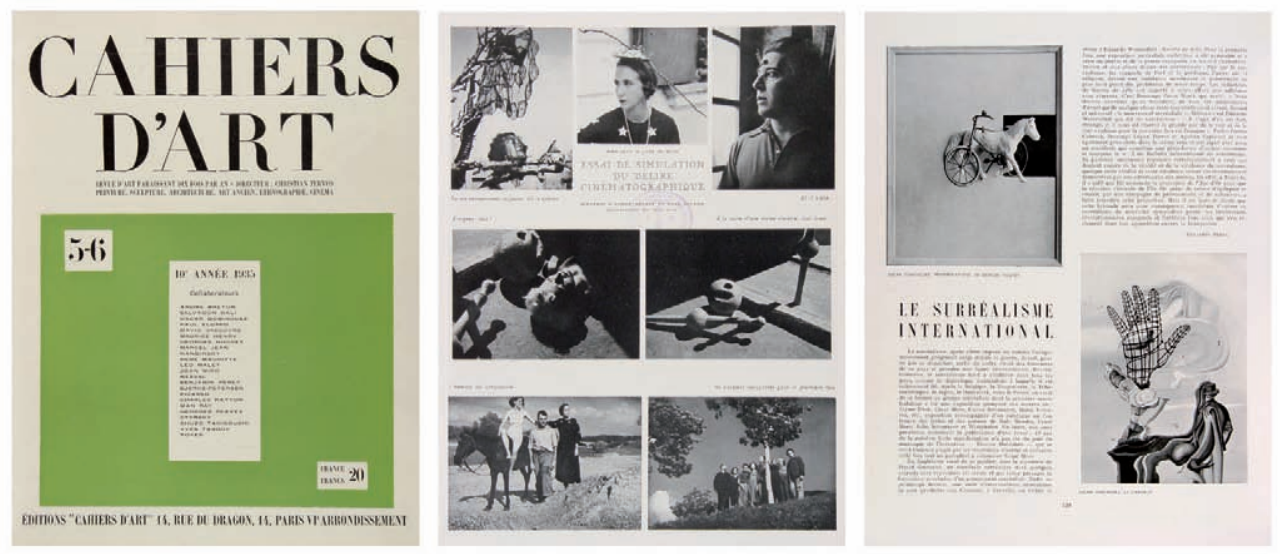

Fig. 13. Cahiers d'Art surrealista: $n^{\circ}$ 5-6 de 1935 (nota 57).- a) Cubierta clásica con sumario de la colaboración de los surrealistas; b) Essai de simulation du délire cinématographique, relato gráfico de Breton, Éluard y Man Ray; c) Surrealismo internacional. El artículo de B. Péret (nota 61).

pasajera pero profunda conversión al surrealismo de tantos números consecutivos de la equilibrada revista de Christian Zervos ${ }^{63}$. Este, como editor y director, mantuvo a distancia el surrealismo; la revista aceptará desde muy pronto a algunos de sus artistas, pero siempre como individualidades y absolutamente desgajados en los comentarios críticos del movimiento y sus razones. Masson, Ernst, Arp, Miró o Giacometti cuentan con artículos monográficos en Cahiers d'Art antes de 1932, en ellos los críticos hacen una lectura estética de sus obras, valoradas por su intensidad plástica asociada ahora a una renovada experiencia de lo primigenio. Al tiempo que los jóvenes artistas del surrealismo afianzan su espacio en los Cahiers, los escritores aparecen tímidamente en sus páginas con textos críticos debidos a Tzara, Hugnet, Arp, Breton o Éluard. Esta apertura tan inevitable como parcial, no le impidió a Zervos manifestar a menudo su escepticismo hacia el surrealismo como movimiento, manteniendo prevenciones hasta fechas tan avanzadas como 1935, cuando escribe: “¿No es peligroso para los jóvenes trazarse a priori un programa, o dejarse imponer uno por unos literatos de talento pero que nada entienden de arte, para, acto seguido, ponerse a rellenar exactamente como los candidatos al Premio de Roma" ${ }^{64}$. La alusión a los escritores del surrealismo es tan meridianamente clara como la relativa a la pintura con la que nunca llegó a transigir: Dalí o Magritte que habrían cruzado esa aludida línea "literaria" que les convertía en émulos de los premios de Roma. Aunque chocante al valorar tales opiniones, Cahiers d'Art integrará acto seguido y a todos los efectos, el gran

63 Sobre Christian Zervos y su revista trato en: MAÑERO, J. (2010). Christian Zervos y Cahiers d'Art; la invención del arte contemporáneo. Locus Amoenus, 10, 279-304. El único monográfico disponible es: DEROUET, C, (2006). Cahiers d'Art. Musée Zervos à Vézelay. París: Hazan / Conseil général de 1'Yonne.

64 ZERVOS, C. (1935). Enquête. Cahiers d'Art, 1-4, 5-17, p. 8. 

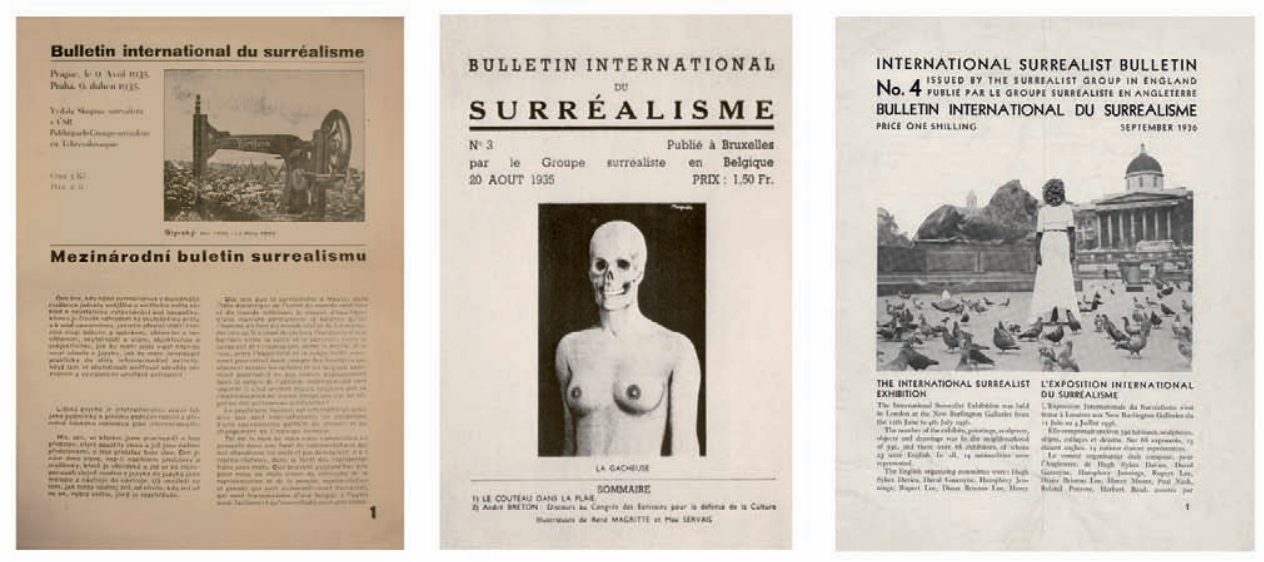

Fig. 14. Bulletin international du surréalisme (nota 63).- a) Portada del $\mathrm{n}^{\circ} 1$. Praga, abril de 1935; b) Portada del n ${ }^{\circ} 3$. Bruselas, agosto de 1935; c) Portada del n ${ }^{\circ} 4$. Londres, septiembre de 1936.

prestigio con que, ya mediada la década, contaban las actividades de los surrealistas, decisión, por otra parte, editorialmente muy razonable.

[Figs. 13 c. 14.15 a.] Surrealismo internacional y pintura.- Enquête, el artículo que contenía la anterior cita, pertenece al no 1-4 de 1935, pues bien, sin más dilación y con ocasión de las exposiciones internacionales del grupo surrealista en Tenerife y Copenhague, Zervos acuerda con Breton dedicar a la actividad del grupo surrealista la próxima entrega de la revista, el $\mathrm{n}^{\circ}$ 5-6 de mayo de 1935 . El resultado fue un documento escorado muy exclusivamente al arte, pero de un surrealismo completo, aunque extravertido y complacido. La puesta en página, siempre supervisada personalmente por Zervos, era la propia de los Cahiers d'Art y entre los artículos hallamos Toile vide, etc., texto apasionado del gran amigo personal de Zervos, Wassily Kandinsky seguido de dos páginas de su obra más reciente. Pero, por lo demás, todos los contenidos pertenecen o bien son asimilables al surrealismo, con una peculiaridad que desde el punto de vista grupal distingue y aporta interés a este fascículo, se trata de la variada participación internacional, una orgullosa manifestación de la vitalidad del movimiento a través de comunicaciones de diversos grupos surrealistas del extranjero. Breton abre el número con Préface aux expositions surréalistes de Copenhague et de Ténerife que en absoluto es crítica ni descripción de tales eventos, sino pura teoría del arte surrealista puesto en relación con el materialismo dialéctico, cuya orientación no sería ya la representación sino la objetivación: "La pintura y la construcción surrealistas permiten, en relación a los elementos subjetivos, la organización de 
percepciones de tendencia objetiva" ${ }^{65}$. Por su parte, Péret, que junto a Breton había inaugurado la Exposición Internacional del Surrealismo en Tenerife, cierra el fascículo con Le Surréalisme international donde constata la inevitable vocación internacional del movimiento: "Revolucionario, el surrealismo tiende a infiltrarse en todos los países, como la dialéctica materialista a la que está íntimamente ligado" 66 . Tras referirse a los muchos países donde ya arraigó, alude a Inglaterra y el manifiesto surrealista escrito por David Gascoyne que aparece en páginas interiores y se detiene especialmente en el grupo de Tenerife y sus actividades alrededor de Gaceta de Arte ${ }^{67}$, la revista dirigida por Eduardo Westerdahl, y a su implicación en el $\mathrm{n}^{\mathrm{o}} 2$ del Boulletin international du surréalisme ${ }^{68}$. El grupo canario al completo firma en páginas interiores Déclaration, una incondicional adhesión al surrealismo, y su artista más reconocido, Oscar Domínguez, es destacado con una importante representación icónica en el fascículo. Otras comunicaciones, en ocasiones de un contenido político que recuerda Le Surréalisme ASDLR, proceden, efectivamente, de Checoslovaquia, Japón, Bélgica o Dinamarca.

[Figs. 13 b. 15 b.] Aun siendo tal internacionalismo lo grupalmente más peculiar, hay destacar otros contenidos de esta memorable entrega de Cahiers d'Art, pues la representación surrealista así como su dedicación al arte del grupo es completa. Más que en ningún otro caso, los textos se vinculan directamente a los artistas y a las excelentes reproducciones que les ofrece la gran revista de arte. La serie es deslumbrante: Éluard prologa con su poema Max Ernst cinco obras de 1935 del pintor, exactamente como hace Péret en Yves Tanguy ou l'anatife torpille les jivaros, compuesto por una larga sucesión de asociaciones libres: "- ¿Si fuera un elemento? -Sería el aire" ${ }^{69}$ que acompañan fantásticas imágenes de obras recientes. Dalí avala sus propias obras con Les eaux où nous negeons, como también Magritte con su texto Le fil d'Ariane. Man Ray titula À l'heure de

65 BRETON, A. (1935). Préface aux expositions surréalistes de Copenhague et de Ténerife. Cahiers d'Art, 5-6, 97-98, p. 98. En nota al pie se indica: "Extraído de "Position politique du surréalisme" que aparecerá el 1 de noviembre de 1935 en Editions du Sagittaire”

66 PERET, B. (1935). Le surréalisme international. Cahiers d'Art, 5-6, p.138.

67 Entre 1932 y 1936, a lo largo de 38 números, la Gaceta de Arte realizó desde Tenerife una asombrosa labor difusora del arte y la cultura internacional, desde el racionalismo arquitectónico hasta el surrealismo. La declaración surrealista del grupo que la promovía se manifiesta particularmente en los números 34 y 35 de marzo y septiembre de 1935. Sobre esta revista pueden encontrarse numerosos estudios y catálogos de exposiciones. Reimpresión: Gaceta de Arte 1932-1935. (1989). Colegio Oficial de Arquitectura de Canarias.

68 La primavera de 1935, los matrimonios Breton y Éluard visitan al sólido grupo surrealista de Praga. En mayo los Breton acompañados por Benjamin Péret se desplazan a Tenerife con ocasión de la Exposición Surrealista organizada por el entusiasta grupo reunido alrededor de Gaceta de Arte. Un año después Breton, Éluard y Dalí participan activamente, junto al grupo local, en la organización de The International Surrealist Exhibition en Londres. Surge paralelamente la idea de dar forma al carácter definitivamente internacional del movimiento con el Bulletin international du surréalisme. Desde Praga, Tenerife, Bruselas y Londres se editan sucesivamente, en la lengua propia y en francés, los cuatro números que componen esta publicación. Reimpresión: Bulletin International du Surréalisme, avril 1935 - septembre 1936. (2009). París: Bibliothèque Mélusine. Presentación de Georges Sebbag. La colección queda también referenciada en: CHÉNIEUXGENDRON, J. et alt. (1994). Inventaire analytique de revues surréalistes ou apparentées. Le surréalisme autour du monde 1929-1947. París: CNRS Éditions.

69 PÉRET, B. (1935). Yves Tanguy ou l'anatife torpille les jivaros. Cahiers d'Art, 5-6, 109. 

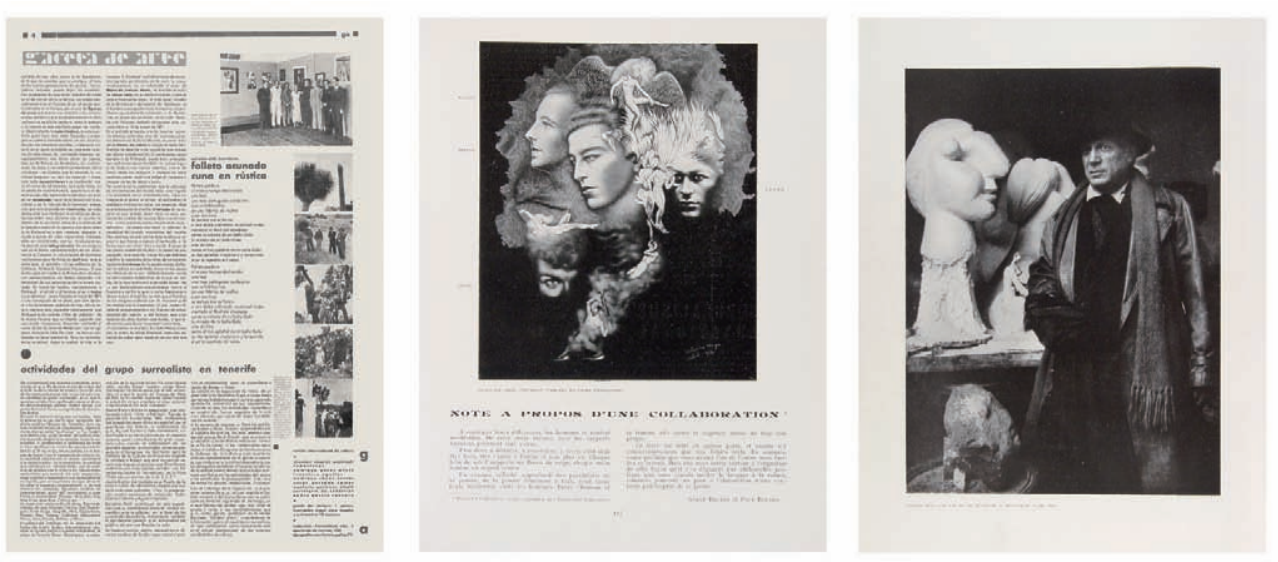

Fig. 15. Gaceta de arte y Cahiers d'Art 1935.- a) Pág. de Gaceta de arte dedicada a la visita de Breton y Péret a Tenerife (nota 62); b) Portrait des poètes surréalistes (inacabado): Éluard, Breton, Tzara y Crevel, de V. Hugo en Cahiers d'Art n ${ }^{\circ}$ 5-6; c) Picasso en su estudio de Boisgeloup, imagen de Cahiers d'Art $\mathrm{n}^{\mathrm{o}}$ 7-10, homenaje de los surrealistas a Picasso.

l'observatoire... les amoureux, tanto sus célebres labios sobre el cielo, como el texto que acompaña esta y otras pinturas. También Miró y un Kandinsky fácil de integrar en esta sinfonía surrealista. Breton, por su parte, publica Automatisme de la variante además de dos páginas ilustradas muy notables: la maqueta de las cinco puertas Rêve-objet con su detallada explicación y Essai de simulation du délire cinématographique, relato gráfico historiado por Breton y Éluard, y fotografiado por Man Ray; sin duda, la página más emblemática de la entrega. La etnografía, querida tanto por Zervos como por los surrealistas, es confiada a Éluard que en La nuit est à une dimensión se apoya sobre una amplia selección de máscaras inuit, el último descubrimiento etnográfico, para desarrollar un texto de gran intensidad mítica y antropológica, excelente ejemplo del uso que tras el contacto con Documents hicieron de la etnografía los surrealistas. Éluard y Breton tienen un momento dulce, de gran colaboración en este Cahiers lo que certifican al incluir Note a propos d'une collaboration, en realidad la introducción a su libro conjunto L'Immaculée Conception (1930) y hacerlo en lugar especialmente destacado del fascículo: bajo el retrato colectivo de Valentine Hugo que se presenta aún inacabado; una manifestación más de la importancia dada por el grupo a este documento, el más específicamente artístico de cuantos concibieron.

[Fig. 15 c.] Homenaje del surrealismo a Picasso.- En la tapa posterior de ese $\mathrm{n}^{\mathrm{o}}$ 5-6 de los Cahiers se anunciaba la siguiente salida y su dedicación a la obra de Picasso entre 1932 y 1935, suerte de continuación del mítico monográfico Pi- 
casso/Bénin ${ }^{70}$. Diez años atrás Picasso, junto a De Chirico, era el gran referente artístico del surrealismo y a quien más ilustraciones reservó $L R S$, ahora con este $\mathrm{n}^{\circ}$ 7-10 de Cahiers d'Art, correspondiente al otoño de 1935, el grupo surrealista cierra un círculo homenajeando al artista. En esta segunda colaboración con los surrealistas, el papel que se reserva Zervos, apasionado de Picasso, sí es relevante, con un importante texto: Fait social et visión cosmique, y una suerte de entrevista: Conversation avec Picasso. Por lo demás, el gran protagonista es Picasso con infinidad de reproducciones de pintura y escultura además de imágenes del estudio y retratos: el modelo fotográfico establecido en Picasso dans son élément se hace manifiesto aquí y allá. La revista da mucha importancia a la Exposició Picasso que Amics de l'Art Nou (ADLAN) estaba preparando en Barcelona para comienzos del año siguiente -primera en España que también viajó a Bilbao y Madrid- e incluye varios textos que fueron radiodifundidos por Radio-Barcelona. Así, bajo el título Desde París, Juli González, -con una convencida defensa del catalanismo de Picasso-, Joan Miró, y Salvador Dalí -"Salvador Dalí té el gust d'invitar a tots els putrefactes insepuls, a tots els pintors d'arbres, mes u meins olotins, a tots els socis i abonats a l'Orfeó Català a visitar l'Exposition Picasso (sic)" "71 - escriben en catalán sobre el proyecto de exposición. Jaime Sabartes presenta en castellano una importante primicia con La literatura de Picasso. La mayor parte de las contribuciones proceden, no obstante, del surrealismo: Breton, Dalí, Éluard, Hugnet, Péret o Man Ray loan con textos más analíticos o más literarios al artista que ha sabido persistir siempre en el límite. Breton analiza su poesía en Picasso poète. Hugnet celebra en L'Iconoclaste su soberana libertad, "la imperturbable agresividad de su obra"72, Dalí aporta uno de sus textos más difundidos Les pantoufles de Picasso, también Péret o Man Ray. Éluard abre esta amplia participación surrealista con Je parte de ce qui est bien, texto compuesto por fragmentos de una conferencia vinculada a la Exposición Picasso en España: "Hablo de lo que me ayuda a vivir, de lo que está bien. No soy de aquellos que buscan la evasión y el olvido no amando nada, reduciendo sus necesidades, sus gustos, sus deseos, conduciendo su vida, es decir la vida, a la repugnante conclusión de su muerte"73. Picasso, que dice usar rojo si no tiene azul, asume, según Éluard, la vida y conoce lo real, restableciendo con su arte el contacto entre el objeto y quien lo ve.

70 Se trata del no 3-5 de 1932 de Cahiers d'Art, el más amplio monográfico sobre Picasso aparecido hasta ese momento. Pero conviene recordar otro precedente más próximo al espíritu surrealista, la entrega de Documents dedicada íntegramente a Picasso: Homage à Picasso, el no 3 de 1930 de la revista.

71 GONZÁleZ, J., MIRÓ, J. y DALÍ, S. (1935). Desde París, Cahiers d'Art, 7-10, 242-244, p. 244.

72 HUGNET, G. (1935). L'Iconoclaste, Cahiers d'Art, 7-10, 218-220, p. 220.

73 ÉLUARD, P. (1935). Je parte de ce qui est bien, Cahiers d'Art, 7-10, 165-168, p. 165. 


\section{El objeto surrealista en las revistas}

[Fig. 5.] Teoría y práctica del objeto.- La pasión surrealista por el objeto y su equívoca situación entre lo real, lo útil y lo simbólico es tan antigua como el grupo y ya manifiesta en Dadá; para los de París los impenetrables objetos ready-made de Duchamp eran manifestaciones del surrealismo. Pero la eclosión madura y la teoría asociada al objeto y sus desplazamientos semánticos tarda en llegar, lo hace tras intensas reuniones del grupo en la primavera de 1931cuyo fruto se hará público en el n ${ }^{\circ} 3(12 / 1931)$ de Le surréalisme ASDLR, entrega caracterizada por aportar ya un corpus definido acerca de la aproximación surrealista al objeto y numerosos ejemplos prácticos de esta nueva línea de investigación. En L'objet fantôme, Breton sitúa la iniciativa en Dalí: "Recientemente he insistido ante todos mis amigos para que pongan en marcha la proposición de Dalí acerca de la fabricación de objetos 'animables' (sic), manifiestamente eróticos, quiero decir, destinados a procurar, por medios indirectos, una emoción sexual determinada" "74. Es, efectivamente, Dalí quien en $\mathrm{Ob}$ jets surréalistes desgrana un "catálogo general" de "los objetos de funcionamiento simbólico" e incluye descripciones de las primeras experiencias, objetos de Hugo, Breton, Gala o él mismo, que aparecen después reproducidos en el cuadernillo de imagen del fascículo citado. Pero, como es sabido, el objeto que permitió entrever la idea de objeto-fantasma y desencadenó la nueva actividad, es la Boule suspendue de Giacometti, el primero de los objetos aducidos por un Dalí especialmente entusiasmado por la dimensión "extra-artística" de la nueva práctica. El grupo entero sin diferencia entre artistas o literatos se entregará al enigma del objeto: "Los museos se llenarán rápidamente de objetos cuya inutilidad, dimensión y desorden obligará a construir torres especiales en los desiertos para contenerlos"75. LS.ASDLR mantuvo hasta el final la poética surrealista acerca del objeto tanto en imágenes como en textos. Así, por ejemplo, las encuestas aparecidas en su última entrega, el n ${ }^{\circ} 6(5 / 1933)$, Recherches expérimentales, donde se preguntaba: Sur la connaissance irrationelle de l'objet boulle de cristal des voyantes o bien de un morceau de velours rose, además de otras cuestiones ${ }^{76}$.

[Fig. 16 a.] El mes de junio de ese mismo año 1933 tiene lugar en la galería Pierre Colle la primera exposición surrealista dedicada principalmente al objeto. Cahiers d'Art la reseñó solo brevemente en un texto atribuible a Zervos donde, una vez más, muestra un interés lleno de reservas hacia el movimiento surrealista. Las obras expuestas eran importantes, como muchas de Giacometti: Le Palais, L'Heure des traces, La table surréaliste, etc. Habrá que esperar hasta 1936 para asistir a la segunda exposición surrealista dedicada, ahora sí, exclusivamente al objeto. Se trata de la Exposition surréaliste d'objets que se celebró el mes de mayo con gran resonancia

74 BRETON, A. (1931, diciembre). L'objet fantôme, Le surréalisme au service de la Révolution, 3, 20-22, p. 22 .

75 DALI, S. (1931, diciembre). Objets surréalistes. Le surréalisme au service de la Révolution, 3, 16-17, p. 17. Dalí cuestionó después la adecuación de las esculturas de Giacometti a estas prácticas acerca del objeto, pues pertenecían al ámbito del arte.

76 Doc. colectivo. (1933, mayo). Recherches expérimentales. Le surréalisme au service de la Révolution, $6,10-24$. 

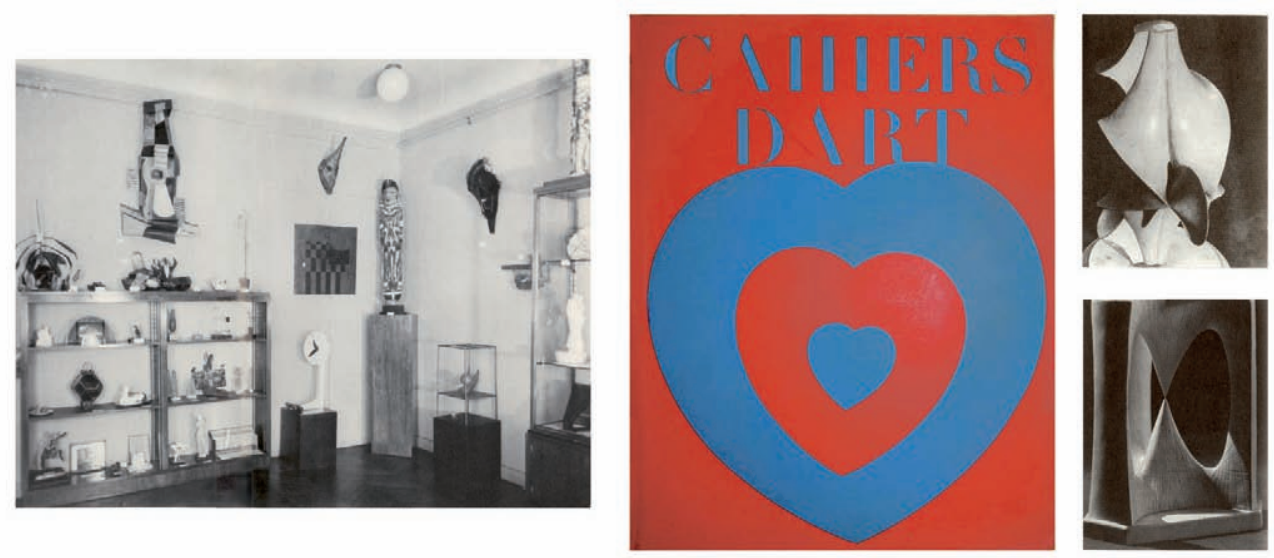

Fig. 16. Cahiers d'Art, no 1-2 de 1936. L'objet.- a) Vista de la Exposition surréaliste d'objets en Charles Ratton; b) Cubierta del fascículo: Coeurs volants de M. Duchamp; c, d) Los objetos matemáticos fotografiados por Man Ray y comentados en Crise de l'objet por Breton (nota 71).

en la galería del marchante especializado en artes primeras y próximo a los surrealistas Charles Ratton. Este reunió en las vitrinas y paredes de su pequeña galería al grupo surrealista más numeroso, con alrededor de 200 obras en catálogo entre las cuales, muy significativamente, como otra clase más de objetos surrealistas -Objets sauvages-, unas 30 piezas de América y Oceanía. Otra clase, porque la exposición pretendía constituirse en taxonomía de los posibles objetos surrealistas según sus procedencias, procesos de formación, fabricación o selección.

[Fig. 16 b, c, d.] Cahiers d'Art: L'objet.- Tal como ocurriera con los anteriores números surrealistas de Cahiers d'Art, una exposición será el desencadenante de esta nueva colaboración de la revista de Zervos con los surrealistas y, sin duda, la más célebre. L'objet [Objets mathématiques. Objets naturelles. Objets sauvages. Objets trouvés. Objets irrationnels. Objets ready made. Objets interpretés. Objets incorporés. Objets mobiles], tal reza título y subtítulo del no 1-2, de 1936, de Cahiers d'Art, una entrega que el propio Zervos debió de percibir como excepcional cuando, contra toda la práctica de la revista, que hasta ese momento había mantenido un característico diseño de cubierta cuyo color variaba en cada entrega, ofrece una portada especial a Marcel Duchamp. Este propone Coeurs volants, una distorsión visual basada en contrastes de tono relacionada con la óptica de precisión de sus recién patentados $R O-$ toreliefs. El fascículo recoge en imágenes una importantísima muestra de lo expuesto en Charles Ratton, que comienza con lo probablemente más sorprendente y comentado en la época, los objetos matemáticos “descubiertos” por Max Ernst y Man Ray 77

77 FORTUNE, I. (1999, mayo). Man Ray et les objets mathématiques. Études photographiques, 6, 1-12, p. 2. Recuperado de http://etudesphotographiques.revues.org/index190.html. 
en el Intitut Poincaré de París. Tal fue su importancia que doce de las fotografías tomadas por Man Ray de esos modelos matemáticos de estudio, aún conservados en el citado instituto, acompañan y determinan los artículos de presentación del fascículo firmados por Zervos y por Breton. El primero, único autor ajeno al ámbito surrealista, abre la paginación del fascículo con Mathématiques et art abstrait, texto donde el crítico y editor se esfuerza de nuevo por aliar sus nociones de raigambre idealista con el surrealismo. Pero donde Zervos demuestra su intuición crítica es al relacionar las perturbadoras formas extraídas de las matemáticas por Man Ray, al mismo tiempo con surrealismo y con abstracción. Precisamente, cuándo el proceso de síntesis entre ambas nociones se estaba produciendo de hecho, especialmente en la escultura. Un proceso al que contribuyeron estas imágenes y este fascículo.

De mayor relevancia en cuanto a la poética surrealista del objeto se refiere, es el fundamental Crise de l'objet de Breton, en buena parte vinculado también a las imágenes matemáticas de Man Ray, aunque ilustrado además con algunos objets naturelles, cristales de bismuto y otras formaciones minerales y fósiles. Breton hace un paralelo, tanto cronológico como significativo, entre las renovaciones poéticas del s. xix, identificadas en Lautréamont y Rimbaud, y el descubrimiento de la geometría no euclidiana que ilustran los "objetos matemáticos". Con ello, poesía y geometría desactivan los hábitos de la causalidad racionalista, los "del bien y del mal". "El desdoblamiento de la personalidad geométrica y el de la personalidad poética han sido efectuados simultáneamente. (...) El pensamiento científico y el pensamiento artístico modernos presentan pues la misma estructura: lo real, demasiado tiempo confundido con lo dado, se expande, tanto para uno como para otro, en todas las direcciones de lo posible y tiende a ser uno con él"78. La poética surrealista del objeto persigue precisamente tal rencuentro sin límites con lo real, a lo largo de este texto fundamental se manifiesta un surrealismo ajeno a ensoñaciones y fantasías, preocupado por situar sus investigaciones en las cosas y los hechos del mundo de manera equivalente a su actividad política revolucionaria. Se trata con diferencia del ensayo fundamental de esta influyente tercera entrega surrealista de Cahiers d'Art que también contiene estudios como el monográfico dedicado a Duchamp: Coeurs volants donde Gabrielle Buffet-Picabia repasa el conjunto de una obra menos conocida por entonces de lo que podría pensarse. Éluard, por su parte, asume de nuevo, como en el $\mathrm{n}^{\mathrm{o}}$ 5-6 de 1935, lo relativo a los Objets sauvages, las máscaras tribales presentes en la exposición, en $L$ 'habitude des tropiques. La fotógrafa Claude Cahun propone uno de los textos más recordados, Prenez garde aux objets domestiques: "No puedo dejar de hablaros de esos objetos que os hablarían mejor por sí mismos, que nos hablarían mejor aun si pudiéramos tocarlos en la oscuridad"79, ilustrado con copas de vidrio deformadas por lava, por Objets naturelles como un gran huevo de Aepyornis, o por muchas obras-objetos surrealistas.

78 BRETON, A. (1936). Crise de l'objet. Cahiers d'Art, 1-2, 21-26. Revisado en GUIGON, E. (Ed.). (2005). L'objet surréaliste (142-147, p. 142). París: Jean-Michel Place.

79 CAHUN, C. (1936). Prenez garde aux objets domestiques. Cahiers d'Art, 1-2, 45-48. Revisado en GUIGON, E. (Ed.). Op. cit. (147-151, p. 148). 
Son parte de las numerosas imágenes de objetos surrealistas aportados a la exposición de Charles Ratton por la mayor parte de los componentes del grupo y reproducidos en L'Objet, entre ellos, el que ya entonces fue más celebrado y hoy icono del objeto surrealista: Le Déjener en Fourrure de Méret Oppenheim que ilustraba precisamente el artículo de Cahun. Finalmente, como no podía ser de otro modo pues sus textos jamás faltaron, la amplia participación de Dalí con varias entradas en sumario, entre las cuales Honneur à l'objet!, que contiene una de esas declaraciones ambiguas situadas en el límite de lo asumible por el grupo: "Declaro que la cruz gamada real y fenomenológica (no la de los hitlerianos que no tienen conciencia de ella), la cruz gamada vieja como el sol chino, reclama el honor del objeto" $"$.

\section{Minotaure 1936: surrealismo vs. crítica de arte}

[Fig. 17 a.] El "continuo" Minotaure.- Cumplida así la intensa etapa surrealista de Cahiers d'Art, Zervos seguirá contando con colaboraciones de los escritores y artistas del surrealismo, como ya lo hiciera antes de esta serie, pero la revista vuelve a su cauce, al arte y sus bellos resultados, como avalan los dibujos de Matisse que ocupan en exclusiva su siguiente entrega. Se cierra así este nuevo y provechoso interludio centrado en lo artístico, a diferencia del anterior, el militante Documents 34, y la cronología nos devuelve al "continuo" Minotaure cuya nueva entrega, su no 8 , verá la luz en junio de 1936. El episodio de reconciliación en la acción política sustanciado en Contre-attaque antes relatado, tiene en esta entrega un destacable correlato poético que, desde el punto de vista de las relaciones entre grupos, caracteriza el número: Bataille aporta aquí su única colaboración para Minotaure. Se trata de Montserrat el relato de una visión mística por él experimentada en aquellos montes catalanes y compartida con Masson, quien ilustra con su traducción plástica el artículo: "Hay que conceder la mayor importancia posible al hecho de que la realidad, se trate de lo que se trate, no puede ser alcanzada sino por el éxtasis religioso" ${ }^{81}$. Tras su breve aproximación política y poética, las diferencias entre Breton y el surrealismo, y la inasumible radicalidad de Bataille, permanecen, aunque como ya se indicó, en una entente respetuosa.

[Figs. 17 b, c. 21 b.] La exaltada visión de Montserrat armoniza con un fascículo cuyos contenidos, muy extremos, encajan bien en el esquema tripartito propuesto más arriba para describir la revista en su conjunto. En el breve texto que introduce la extensa paginación de imagen de La peinture surréaliste, la crítica de arte personificada en Tériade muestra su más decidida asimilación de la década surrealista: "El delirio estético y la inundación pictórica de los primeros años de posguerra, pedían imperiosamente una saludable reacción contra un materialismo de mal gusto, cocinado y académico en el que se oscurecían, por culpa de indiferentes copistas, las manzanas de Cezanne, las guitarras de Picasso y los interiores de Matisse. Esta reac-

80 DALÍ, S. (1936). Honneur à l'objet! Cahiers d'Art, 1-2, 53-56. Revisado en GUIGON, E. (Ed.). Op. cit. (151-155, p.155).

81 BATAILLE, G. y MASSON, A. (1936, junio). Montserrat, Minotaure, 8, 50-52, 2 ilust. (Masson), p. 51. 

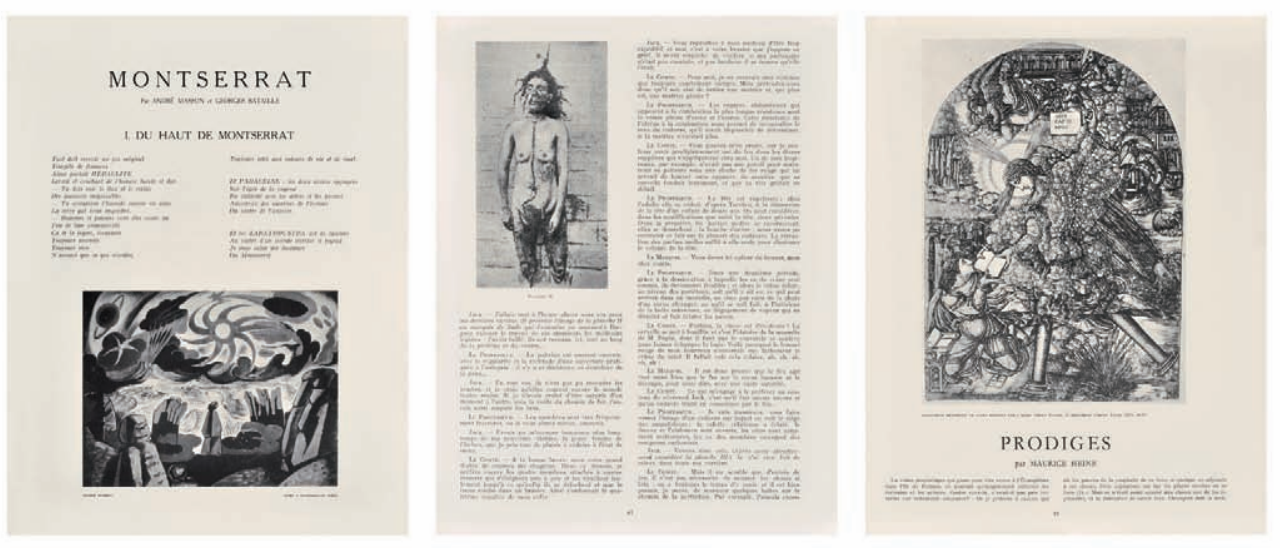

Fig. 17. Minotaure: Lo extremado.- a) Pág. inicial de Montserrat, $n^{\circ} 8,1936$, la única colaboración de G. Bataille (nota 74); b, c) Los límites en M. Heine: Pág. de Regards sur l'Enfer anthopoclasique, nº 8, 1936 y pág. inicial de Prodiges, $\mathrm{n}^{\circ} 10,1937$.

ción, la aporta el surrealismo" 82 . Tras la crítica de arte, el surrealismo más visionario y exigente: En D’une décalcomanie sans objet préconçu, Bretón explica la citada técnica "Para abrir a su voluntad la ventana a los más bellos paisajes del mundo y más allá" ${ }^{83} \mathrm{y}$, de la mano de Péret, se presentan decalcomanías de los miembros del grupo. A continuación, insistiendo en esa clase de formalizaciones del caos y en la idea de paisaje, aunque interior, Breton propone un texto poético y alucinado surgido del viaje a Tenerife, Le Château étoilé que se ilustra con frottages de Ernst, auténticas visiones interiores y anti-postales: "El deseo, único resorte del mundo, el deseo, único rigor dado a conocer al hombre, ¿dónde podría estarse mejor para adorarlo, sino en el interior de una nube? Las formas que, en la tierra, adquieren a los ojos del hombre las nubes no son de ningún modo fortuitas, son augurales" ${ }^{84} \mathrm{El}$ azar objetivo es augural y por lo tanto, tan mágico como inevitable: L'Amour fou sobrevuela este artículo. Finalmente, la herencia de Documents, lo real "sin cocina poética" como aconsejaba Bataille: En Regards sur l'Enfer anthropoclasique, Maurice Heine se asoma como nunca al horror al proponer un dialogo entre sombras, las del Marqués de Sade y Jack el Destripador entre otras, ilustrado con brutales imágenes de cadáveres mutilados.

[Fig. 18.] Casi una revista de arte.- En un vaivén muy propio de Minotaure, el tono extremado al que acabamos de asistir cambia completamente de registro en la siguiente entrega. Con el $\mathrm{n}^{\circ} 9$ de octubre de 1936, último de la $2^{\mathrm{a}}$ serie, se produce un golpe de timón respecto al asentamiento total de los intereses surrealistas en la publicación, mediante el cual Tériade asume realmente la dirección artística de la

82 TERIADE, É. (1936, junio). La peinture surréaliste, Minotaure, 8, 4-17, 31 ilust., p. 5.

83 BRETON, A. y PERET, B. (1936, junio). D’une décalcomanie sans objet préconçu / Entre le Chien et le Loup. Minotaure, 8, 18-24, 10 ilust., p.18.

84 BRETON, A. (1936, junio). Le Château étoilé, Minotaure, 8, 25-39, 6 ilust (Man Ray), p. 35. 

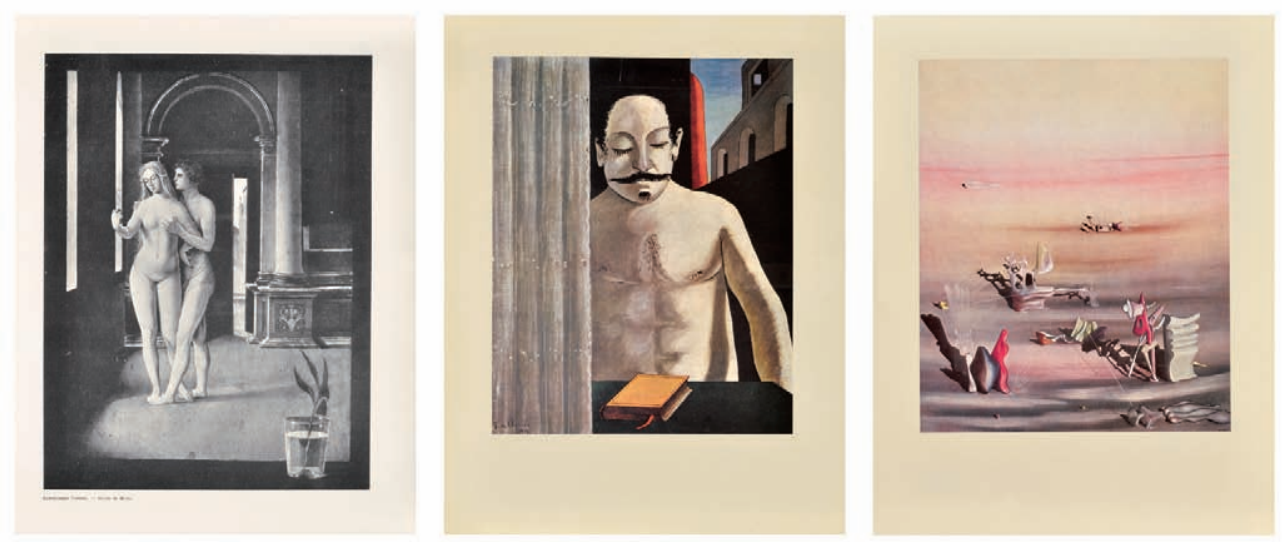

Fig. 18. Minotaure: La pintura.- a) Presencia y apropiación del arte histórico: hors-texte de Bartolomeo Veneto, $\mathrm{n}^{\mathrm{o}}$ 11, 1938; b, c) Algunas obras presentadas por Breton a color en Des tendances les plus récentes de la peinture surréaliste, $\mathrm{n}^{\circ}$ 11-12, 1939 (nota 87): Le Cerveau de l'Enfant de G. de Chirico y La lumière de l'ombre de I. Taguy, nueva referencia de la pintura surrealista.

revista. Efectivamente, este fascículo que sale con cubierta de Matisse, marca con su dedicación al arte y el tono de su crítica, la mayor aproximación a tales intereses hasta el punto de poder confundirse, aunque solo en una rápida hojeada, con una revista de arte al uso. Se trata de un número especialmente lujoso e ilustrado, en él Tériade integró a colegas de la crítica profesional como: Georges Duthuit que presenta $E d-$ gar Degas chez Amboise Vollard; Lionello Ventuti que se ocupa de la obra última de Cezanne; Raynal que presenta un bellísimo trabajo sobre los Cranach; etc. También él mismo, que inicia el fascículo con Constance du fauvisme, ilustrado con obra de Matisse. Son contenidos de máxima calidad perfectamente asimilables a los de las grandes revistas de arte. Sin embargo, sigue tratándose de Minotaure: Breton y Dalí entregan textos de importancia, como también Caillois y Heine. Dalí, además, aporta la única imagen de arte surrealista del número: Espagne, Prémonition de guerre civil, uno de los cinco hors-texte a color que contiene el volumen. Pero los límites puestos por Tériade a la participación surrealista son claros, se persigue un proceso de normalización y diversificación para la revista. Las últimas páginas, con una peculiar contribución de Le Corbusier ${ }^{85}$, o la inclusión de La lumière et les plantes, un artículo de interiorismo adecuado para Art et Décoration, así lo confirman. Pero es un canto del cisne. Esta nueva orientación no tendrá continuidad y tras este esfuerzo Tériade abandona la revista ${ }^{86}$.

85 LE CORBUSIER (1936, octubre). Louis Sutter. L'inconnu de la soixantaiene. Minotaure, 9, 62-65. Paradójicamente, el gran teórico de la estética moderna lleva a Minotaure un artista "propio" de la revista, enajenado e internado, cuyos dibujos deben asociarse a la idea de Art brut.

86 En todo caso, no era Minotaure el único proyecto editorial de Tériade, uno de los grandes revuistes del momento. Al tiempo que disputaba en aquella con los surrealistas, fundaba en 1935 , junto a Raynal, $L a$ 
[Figs. 6 c. 8 a, b. 9. 11 c. 12.] Durante tres años Minotaure había producido nueve números que, a pesar de su disputada dirección y la consiguiente diversidad de intereses, o tal vez precisamente gracias a ello, suponen el momento más intenso y, por así decir, clásico de la revista. Algunos autores que ya no escribirán en la siguiente tercera serie han desarrollado allí ciclos culminantes tanto en lo personal como para Minotaure. Es el caso de Roger Caillois, que con el batailleano Le complexe de midi $\left(n^{\circ} 9\right)$ culmina una trilogía a la que hemos ido asistiendo. Lo es igualmente de Dali, que con Structures molles $\left(\mathrm{n}^{\mathrm{o}} 9\right)$ concluye su asombrosa participación escrita en la revista cuando sus vínculos con el grupo eran ya muy débiles. En cuanto a la parte visual, Brassaï concluye prácticamente su colaboración desde el n ${ }^{\circ}$ 8: en Verve tendrá una nueva plataforma. Por su parte, Breton había aportado los momentos fundamentales de su investigación poética de los años 30, continuando una línea iniciada en Nadja (1928) y Les Vases communicants (1932) que culmina en Minotaure con tres grandes artículos que ya fueron citados en su momento: La beauté sera convulsive $\left(\mathrm{n}^{\mathrm{o}} 5\right)$, La nuit du Tournesol $\left(\mathrm{n}^{\mathrm{o}} 7\right)$ y Le Château étoilé $\left(\mathrm{n}^{\mathrm{o}} 8\right)$, a los que hay añadir Equation de l'objet trouvé publicado como vimos en Documents 34. La reunión de estos artículos -incluida la totalidad de sus imágenes-, que enlazan autobiografía y “azar objetivo", dio lugar a L'Amour fou 87.

\section{Minotaure $3^{\mathrm{a}}$ serie. Lentamente, hacia el final de una era}

La escasez de proyectos editoriales.- La $3^{\mathrm{a}}$ serie de Minotaure se desarrolla lentamente a lo largo de tres años -los mismos que vieron las anteriores nueve entregasentre la salida del $n^{\circ} 10$ en invierno de 1937 y la del no 12-13 de mayo de 1939: tres entregas, una por año. Es un ciclo bien diferenciado por su mayor univocidad surrealista derivada de la toma de la dirección efectiva por parte de Breton y sus amigos, desplazando a la crítica de arte profesional, pero no al arte que se potencia con una gran dedicación al surrealista, e incluso dando cabida a artistas históricos que en el contexto de la revista adquieren rasgos perturbadores: Piero di Cosimo, Botticelli, Géricault o Caspar David Friedrich. Persiste en el frontispicio el editor Albert Skira como director, pero tras él un Comité de redacción compuesto por Breton, Duchamp, Éluard, Heine y Mabille, configura expresamente una revista surrealista. Aunque tal vez no se vuelvan a alcanzar hitos como los se acaban de señalar, Minotaure $3^{\mathrm{a}}$ serie sigue fiel a su ambición, formato e, incluso, diversidad de intereses, sin embargo, la revista, particularmente en sus entregas correspondientes a 1937 y 1938, ha mermado sus posibilidades editoriales y, ya sea por la pérdida de autores como los citados o bien por lo sectario de la nueva dirección ante los suscriptores, lo cierto es que a dife-

Bête noire (1935-1936) o, también, la curiosa revista de viajes Le Voyage en Grèce (1934-1939). Con el nº 9 de Minotaure, Tériade ensaya un modelo de revista lujosa y orientada a una asimilación amplia, al tiempo que moderna del arte. Tras su exclusión por los surrealistas, aplicará de inmediato tal modelo con Verve (1937-1960), "La más bella revista del mundo", auténtico hito bibliográfico del arte moderno que desbanca la exclusividad de Cahiers d'Art, superándola en su renovada concepción visual. Los grandes maestros, Picasso, Braque, Bonnard, Matisse, Miró, despliegan en ella su prodigiosa madurez.

87 BRETON, A. (1937, enero). L’Amour fou. París: Gallimard. 
rencia de las series anteriores, carece de hors-textes a color y prácticamente de carga publicitaria. Por otra parte, esta neta adscripción surrealista tampoco convierte a la revista en verdadero órgano del grupo: Skira mantiene algunos intereses editoriales -el arte histórico forma parte de ellos- y también el veto a la política, además, la escasísima presencia periódica de la revista impide considerarla un vehículo suficiente para la expresión del grupo y mucho menos para su acción.

[Fig. 19 a.] Aunque, como es natural, los surrealistas publicaban a título personal, cuesta identificar durante aquellos años proyectos editoriales de grupo fuera de $\mathrm{Mi}$ notaure, incluso su participación puntual en revistas literarias y de cultura abiertas decae notablemente ${ }^{88}$. Veamos algunos casos que, aunque lejos de la relevancia de los "interludios" ya descritos, deben considerarse como actividad colectiva surrealista. Una de las revistas culturales del momento más frecuentada por sus firmas y dibujos fue Cahiers GLM, una publicación literaria centrada en la poesía editada en cuarto por Guy Lévis-Mano ${ }^{89}$, que logra sacar nueve números entre mayo de 1936 y marzo de 1939. La poesía francesa avanzada-Henri Michaux tiene gran presencia- se presenta en sus páginas con una gran diversidad de tendencias y generaciones, al tiempo que nombres extranjeros como Neruda o García Lorca traducido por el propio editor, también poeta. Éluard, Penrose, Mabille, Crevel, Masson, Bellmer, Man Ray, Seligmann, etc., habían participado ya en esta revista antes de que Lévis-Mano confiase a Breton, que acababa de publicar con él De l'humour noir (1937), la dirección de la entrega $\mathrm{n}^{\circ} 7$ de marzo de 1938 completamente consagrada al sueño. Breton integra a buena parte del grupo surrealista, aunque también a otros como el distanciado Michel Leiris, en un proyecto de contenido netamente poético, pero apoyado por imágenes procedentes del surrealismo artístico. La revista Plastique, editada por Sophie H. Taeuber-Arp entre 1937 y 1939, ocupó con sus cinco números el lugar dejado por Abstraction Création Art non figuratif (1932-1936). Sus páginas recogían en varios idiomas la tradición de las vanguardias rusas, el neoplasticismo, la Bauhaus, Dadá constructivo y la abstracción reciente: Malevich, Arp, Albers, Kandinsky y Magnelli firmaron sus portadas. Sin embargo, como una manifestación más de la nueva sinergia entre abstracción y surrealismo, sus $\mathrm{n}^{\text {os }} 4$ y 5 reciben el título de L'Homme qui a perdu son squelette, el de la novela colectiva que contenían, al modo de Viollet Nozière, compuesta por Arp, Carrington, Duchamp, Eluard, Ernst, Hugnet, G. Pras-

\footnotetext{
88 Aunque la presencia surrealista en algunas revistas literarias fue más constante -es el caso especialmente de Les Cahiers du Sud (Marsella 1923-1966)-, la Nouvelle Revue Française NRF (París 1909-actualidad) constituye un ejemplo significativo de la situación. Esta influyente revista fue fundamental en el apoyo y la difusión de los poetas de Dadá y del posterior surrealismo más allá de las fronteras de los propios grupos. $\mathrm{Su}$ apertura al surrealismo durante 1924 y 1925, tanto por el espacio cedido a sus componentes como por la simpatía mostrada desde la propia redacción, fue determinante en la fulgurante difusión inicial del movimiento. Pero, coincidiendo con la politización del grupo, su presencia y el interés por el surrealismo de la $N R F$ decayó, y entre 1930-1939, el periodo de mayor expansión surrealista, paradójicamente apenas publica 19 textos surrealistas y prácticamente ninguna reseña crítica de esta procedencia. BRIDE, Y. (1988). Miroirs du surréalisme: Essai sur la réception du surréalisme en France et en Suisse française (1916-1939). Lausanne: L'Age d'Homme, 1988, pp. 27-80.

89 Lévis-Mano (1904-1980) fue un poeta, ilustrador y editor muy apreciado en el ambiente literario del momento y famoso por sus ediciones poéticas ilustradas con dibujos de artistas de renombre. También por sus propias creaciones y licencias tipográficas.
} 

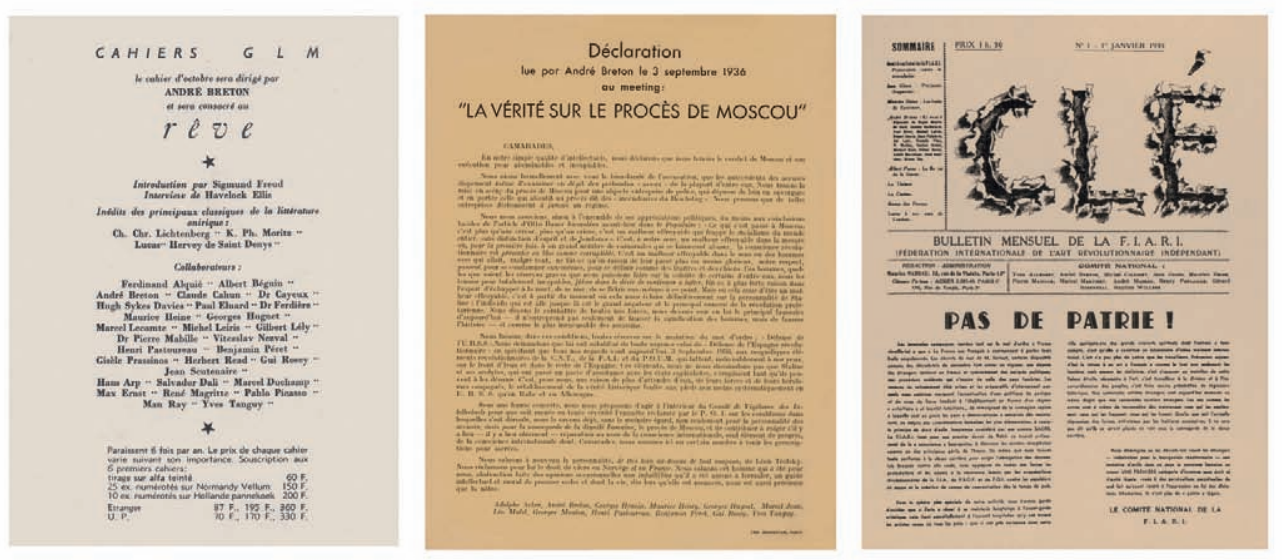

Fig. 19. Otras actividades editoriales y políticas.- a) Pág de sumario de Cahiers GLM "Rêve", n 7, 1938 (nota 79), dirigido por Breton; b) Panfleto contra los procesos de Moscú,

1936 (nota 81); c) Portada de Clé. Bulletin mensuel de la FIARI, nº 1, enero de 1939.

sinos, surrealistas, por mucho que en ese 1939 mantuvieran distancias con el grupo. Finalmente, del "surrealismo otro" de la línea batailleana, hay que recordar Acéphale. (Religion, Sociologie, Philosophie) ${ }^{90}$, el órgano de la comunidad secreta homónima creada por Bataille, que ve cinco números entre 1936 y 1939 en los que Masson es determinante y donde colabora Roger Caillois, ambos vinculados simultáneamente al grupo surrealista.

[Fig. 19 b, c.] Contra (todos) los totalitarismos.- Con todo, la actividad editorial del grupo nunca se había visto tan mermada. Pero los tiempos eran de plomo $\mathrm{y}$, en realidad, es la acción surrealista en su conjunto lo que pierde brillo y carácter colectivo. El grupo se había ampliado notablemente gracias, como a lo largo de toda la década, a la constante afluencia internacional de artistas, pero esto no redundó en compromiso militante, las reuniones se distancian y su asistencia se reduce al residuo del grupo histórico y pocos más. Son, así, muy pocos quienes firman las dos proclamas centradas en la Guerra de España, una fechada el mismo 20 de julio de 1936 y otra en agosto, en la que se trata de traición la "no intervención" del gobierno francés del Front Populaire. Ese mismo mes de agosto tenían lugar los primeros Procesos de Moscú y, en este caso, la respuesta de Breton y su grupo fue más elaborada y ampliamente avalada. En una serie de tres tracts agrupables bajo la denominación de un encuentro celebrado el 3 de septiembre: La Vérité sur les procès de Moscou, se tacha ya sin ambages de totalitario al régimen de Stalin, traidor a la Revolución de octubre y a la Tercera Internacional, previniendo de sus intenciones en España: "Estos elementos (CNT, FAI, POUM fuerzas revolucionarias españolas), sabemos que Stalin y sus acólitos que han hecho un pacto de asistencia con los capitalistas, se emplean tanto

90 Reimpresión: Acéphale $n^{\circ} 1$ à 5, 1936-1939. (1980). París: Jean-Michel Place. Introducción de Michel Camus. 
como pueden para desunirlos. Es para nosotros una razón más para esperar de ellos, de sus fuerzas y sus heroísmos conjugados, el restablecimiento de la verdad histórica, pisoteada no menos sistemáticamente en la URSS que en Italia o Alemania"91. Esta temprana consideración equidistante entre tales regímenes y líderes es grave en aquel contexto, pero no es pasajera o producto del momento, sino la posición definitiva del surrealismo y de otros intelectuales -Bataille, por ejemplo- que se afirmará en la próxima empresa asociativa política iniciada por Breton. Se trata de la Fédération internationale de l'art révolutionnaire indépendant (F.I.A.R.I.), puesta en pie a demanda de Trotsky quien, desde su exilio mejicano, firma en julio de 1938 la declaración inaugural junto al poeta: Pour un art révolutionnaire indépendant: "Toda tendencia progresiva en arte es censurada por el fascismo como degenerada. Toda creación libre es declarada fascista por los estalinistas. El arte revolucionario independiente debe concentrarse en la lucha contra las persecuciones reaccionarias y proclamar decididamente su derecho a la existencia"92. La admiración distanciada y antigua por el padre de la revolución permanente, se hace así aval efectivo, como el que en otros campos siempre buscó Breton, sin acabar de obtenerlo, en Freud. La FIARI, último proyecto político surgido del grupo surrealista antes de la guerra, se hace operativa durante los últimos meses del año y se dota de un boletín, Clé, cuyos dos únicos números, de enero y febrero de 1939 respectivamente, contienen numerosas proclamas del grupo. Masson dibuja para la portada del segundo Le Thé chez Franco.

[Fig. 20 a, b.] La poesía aún.- Con una sola excepción a la que atenderé después, ninguna de estas actividades públicas tuvo su reflejo en Minotaure, fiel a su apoliticismo. En este último tramo de la revista los contenidos literarios mantienen, a pesar de las ausencias, una continuidad razonable, alcanzando también momentos de alta tensión poética y visual. Benjamin Péret tiene una participación especialmente intensa con un artículo en cada fascículo de esta $3^{\mathrm{a}}$ serie, renovando unas entregas que comenzaban con el extraordinario Au paradis des fantômes (n $\left.{ }^{\circ} 3-4\right)$; ahora sus propuestas son menos irónicas, más concisas y poéticamente intensas en su integración de la imagen. Si antes hablábamos de algunas cumbres -Dalí, Caillois, Bretonya coronadas en anteriores momentos de Minotaure, es justo decir que la obra de Péret llega ahora a sus límites con La nature dévore le progres et le dépasse $\left(\mathrm{n}^{\mathrm{o}} 10\right.$, invierno 1937), con A l'interieur de l'armure ( ${ }^{\circ} 11$, mayo 1938) y, especialmente, con el entrópico y visualmente fascinante Ruines: ruine des ruines ( $\mathrm{n}^{\circ} 12-13$, mayo 1939): "pero tal vez se encuentre algún día, cuando su recuerdo se haya borrado de la memoria de los hombres, el gigantesco fósil de un animal único, la torre Eiffel" ${ }^{93}$

91 BRETON, A (1992). La Vérité sur les procès de Moscou. En BRETON, A. (Ed. M. Bonnet et alt.). Op. cit., (1200-1202, p. 1201). En el último de estos Meeting Breton es aun más explícito respecto a Stalin, proclamando en su conclusión: "Camaradas, estaréis de acuerdo conmigo (...) en poner toda vuestra confianza en la vanguardia revolucionaria catalana y española para que no se desgarre a sí misma y salvar, a pesar de Stalin como a pesar de Mussolini y de Hitler, el honor y la esperanza de nuestro tiempo" BRETON, A. (1992). Discours de 26 Janvier 1937 au "Meeting" du P.O.I. sur le second Procès de Moscou. En Ibídem, (1207-1212, p. 1212).

92 BRETON, A. y TROTSKY, L. (1980). Pour un art révolutionnaire indépendant. En PIERRE, J. (Ed.), Op. cit., (335-339, p. 338).

93 PÉRET, B. (1939, mayo). Ruines: ruine des ruines. Minotaure, 12-13, 57-65, 12 ilust., p. 61. 

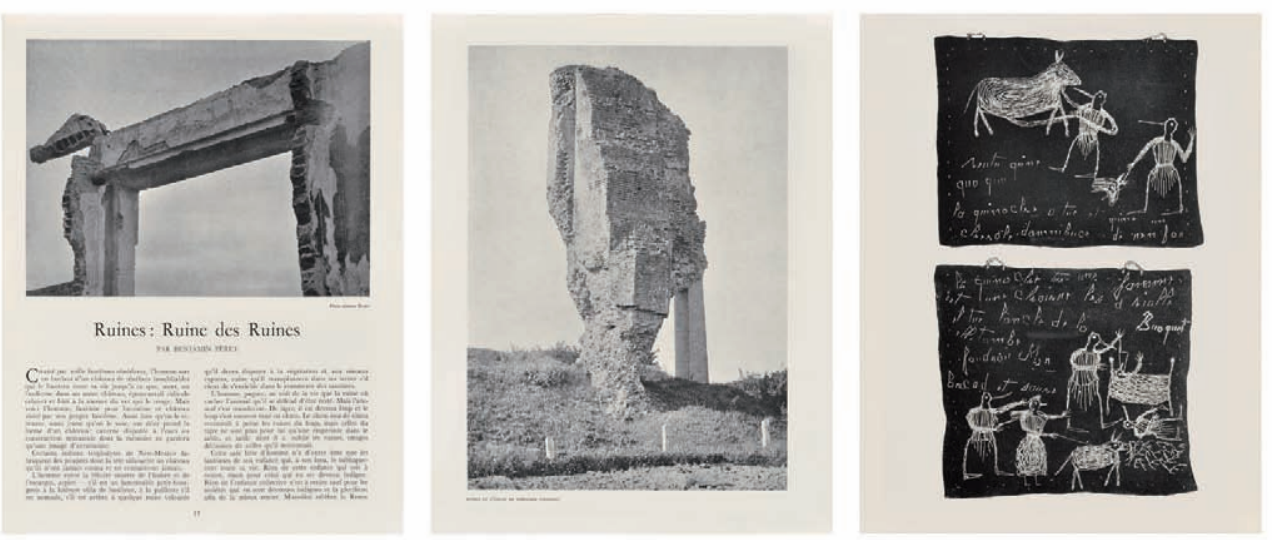

Fig. 20. Minotaure: Los poetas.- a, b) Ruines: ruine des ruines, $\mathrm{n}^{\circ} 12-13,1939$ de B. Péret (nota 83). Pág. inicial y pág. con una de sus ilustraciones de ruinas medievales; c) Juste Milieu, $\mathrm{n}^{\circ} 11,1938$ de P. Éluard. Una de sus numerosas páginas con obras de enajenados presentadas sin identificación alguna.

puede leerse en columna contigua a Fossile de la Tour Eiffel, fotografía "fosilizada" de Raoul Ubac. Péret, junto a Heine, Éluard y el propio Breton son los únicos escritores de primera hora que permanecen; Pierre Mabille el más destacado entre los recientes ${ }^{94}$. Heine mantiene imperturbable su regularidad de artículo por entrega y su poder perturbador, rascando en los resquicios y los olvidos del arte y la cultura. Imágenes dislocadas de un Apocalipsis del s. XVI en Prodiges ( $\left.\mathrm{n}^{\circ} 10\right)$, temibles deidades tutelares tibetanas en una cópula eterna en Eritis sicut dii... ( $\left.\mathrm{n}^{\circ} 11\right)$ o Maldoror et la belle dame, su participación en Documents inédits sur le Comte de Lautréamont $\left(\mathrm{n}^{\circ}\right.$ 12-13), el monográfico sobre quien fuera primer y siempre referente intacto del surrealismo que, a modo de confluencia astrológica, completa el círculo del surrealismo histórico cerrando las páginas finales de la colección de Minotaure.

[Fig. 20 c.] En cuanto a Paul Éluard, el gran poeta, su especificidad en este campo literario, que no ha sido objeto de este estudio, le ha restado el protagonismo que su relevancia en el grupo surrealista y amplia presencia en la revista justifica. Sin embargo, estuvo entre quienes supieron apropiarse de la herencia de Documents creando artículos que actúan más allá de lo literario. Les plus belles cartes postales (nº 3-4) presenta en 12 páginas una amplísima colección de ellas tan surrealista como los autómatas de Péret. El estudio que precede tal sucesión, se complace en este género popular al que aplica ciertas taxonomías, lo encuentra tan digno de ser tenido en cuenta como todas las cosas pequeñas y minuciosas del mundo: "Somos a menudo ese hombre que en la calle se agacha para ver mejor los niños, los insectos, las flores

94 Pierre Mabille tiene su primera colaboración en el $n^{\circ}$ 6. Miroirs, un bello estudio sobre el espejo y el reflejo publicado en el $n^{\circ} 11$, es su colaboración más recordada. Raoul Ubac lo ilustra con algunas de las imágenes más emblemáticas de Minotaure. 
y las mujeres, ese hombre sirviente del mundo, ese hombre que se agacha para alzarse de nuevo, llevando más alto que él todo lo que dominaba"95. Esta recopilación pormenorizada de elementos digna de un coleccionista -las postales procedían de su propia colección-, determinará formalmente la estructura de la mayor parte de sus artículos. Así es en Physique de la poésie ( ${ }^{\circ}$ 6), un estudio sobre la ilustración literaria basado en una amplia y sistemática serie casos. También, en los dos que aporta a esta $3^{\mathrm{a}}$ serie: Premières vues anciennes $\left(\mathrm{n}^{\mathrm{o}} 10\right)$, un ensayo sobre poesía que avanza al hilo de infinidad de fragmentos, citas y aforismos de toda procedencia hasta concluir con Lautréamont: "La poesía debe estar hecha por todos. No por uno ${ }^{96} ;$ y Juste Milieu $\left(\mathrm{n}^{\mathrm{o}}\right.$ 11) cuyo texto netamente poético da paso a una larga serie de obras artísticas de enajenados. Es la última aportación, su colaboración con Aragon en Commune, la revista de la AEAR difusora del realismo socialista literario y su ortodoxia, decide a Breton a romper definitivamente con él a finales de 1938.

\section{La revista con cabeza de animal: surrealismo proyectado al futuro}

[Figs. 18, 22.] Automatismo absoluto.- En la página de presentación del n ${ }^{\circ} 11$, Breton disculpaba su participación por haberse precipitado su viaje a Méjico, donde parte en septiembre de 1938 comisionado por el gobierno francés para desarrollar un ciclo de conferencias sobre literatura y arte: "Pero os hablaré después de Méjico" promete a sus lectores. Ciertamente lo cumple, aunque al cabo de un año, en el número 1213 de mayo de 1939, último de La revue à tête de bête, tal como es designada en la presentación. Se trata de un fascículo donde la pintura tiene gran protagonismo y que, a su vez, contiene en su interior otro dedicado exclusivamente a Méjico. En ambos, Breton tiene un papel determinante. Su interés por mostrar en esta ocasión la pintura de la nueva generación surrealista de la mejor manera, le lleva a exigir recuperar y ampliar la imagen en color que faltó en las entregas anteriores, logrando el fascículo más rico en este sentido. Tal interés era, por otra parte, muy específico, como demuestran los dos textos que dedica de su pluma al arte, amén de otros contenidos en la entrega como el que Pierre Mabille centra en Victor Brauner, L'oeil du peintre $\left(\mathrm{n}^{\mathrm{o}}\right.$ 11-12) construido alrededor del desgraciado suceso que le costó al pintor su ojo izquierdo, o los dedicados a Géricault y a Caspar-David Friedrich, casi una primicia en Francia. El primero de estos textos de Breton se centra en Masson, cuyo cuaderno de dibujo Massacres $\left(\mathrm{n}^{\circ} 1\right)$ inauguraba la presencia del arte surrealista en Minotaure, y ahora vuelve en Prestige d'André Masson (n ${ }^{\circ} 11-12$ ), el tercer monográfico de artista consignado por Breton en la revista tras los ya comentados de Picasso $\left(n^{\circ} 1\right)$ y Duchamp $\left(\mathrm{n}^{\circ} 6\right)$. Masson es propuesto ejemplarmente como el artista integro y uno de los pocos a la altura de unas circunstancias que el poeta sabe calibrar: "Confunde observar que, al inicio de 1939, el arte en Francia parezca ante todo preocupado por esparcir un tapiz de flores sobre un mundo minado. Cuando un viento de destrucción

95 ÉLUARD, P. (1933, diciembre). Les plus belles cartes postales. Minotaure, 3-4, 85-100, 125 ilust., p. 88.

96 ÉLUARD, P. (1937). Premières vues anciennes. Minotaure, 10, 49-56, p. 56. 

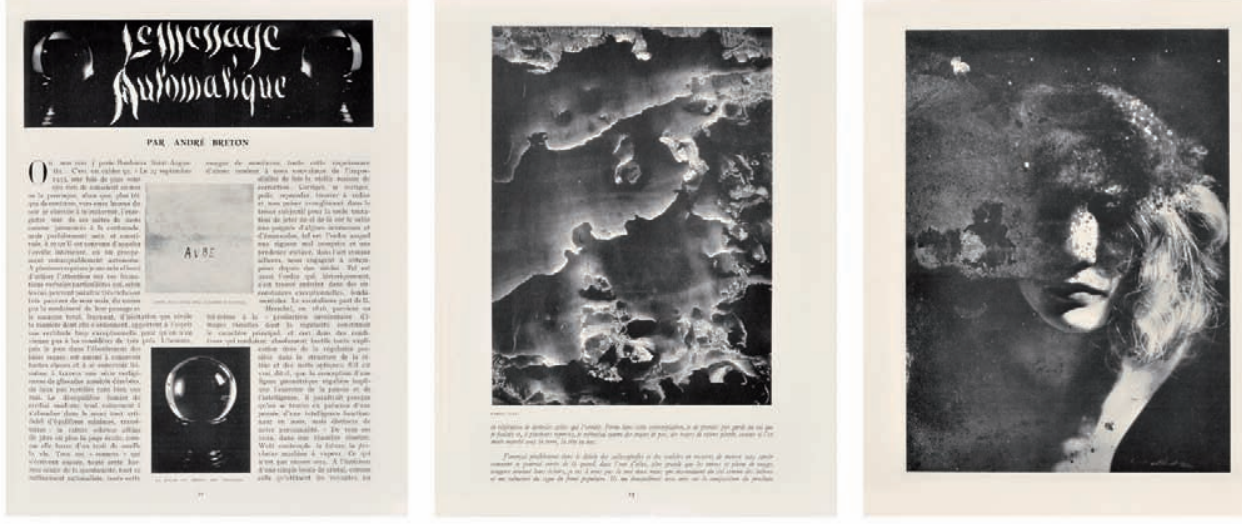

Fig. 21. Minotaure: Recalificaciones del automatismo.- a) Pág. inicial de Le Message automatique, $\mathrm{n}^{\circ} 3-4,1933$ de A. Breton (nota 89); b) D’une décalcomanie sans objet préconçu / Entre le Chien et le Loup, $\mathrm{n}^{\circ}$ 8, 1936, de Breton y Péret. Decalcomania de Marcel Jean (nota 76); c) Ilustración de Raoul Ubac para Miroirs, $n^{\circ} 11,1938$, de P. Mabille. Un automatismo fotográfico.

golpea todas las puertas (...) y por doquier los días de la libertad parecen contados"97. La obra de Masson sí procede de la "tragedia y la aprensión de la época", es "obra de arte-acontecimiento", riesgo antes que perfección, atenta a la revelación.

[Figs. 18 b, c. 21.] Por idénticas razones, Masson es también ejemplo para lo que Breton propone a continuación en Des tendances les plus récentes de la peinture surréaliste ( $\mathrm{n}^{\mathrm{o}}$ 11-12), donde se constata y se defiende la vuelta al "automatismo absoluto" demandado hace tanto en el Manifeste du surréalisme. "La pintura surrealista, en sus manifestaciones más recientes (...) opera un marcado retorno al automatismo" 98 afirma Breton antes de describir algunos de los nuevos procedimientos desarrollados por Dominguez, decalcamonie, por Paalen, fumage, incluso la escultura con el lithochronisme, "mecanismo de solidificación del tiempo", desarrollado por Séligmann o la compleja mezcla de procesos aplicados por Ubac a la fotografía. Estos procedimientos depuran respecto a los ya clásicos del collage y frottage, la acción no voluntaria del artista y superan definitivamente el abandono figurativo. Dalí, el máximo y más influyente ejemplo de tal posibilidad ha acabado, según Breton, convirtiendo su obra en un "divertimento del orden de los "crucigramas". Para los jóvenes la referencia ya no es aquél sino Tanguy cuyo "secreto permanece tan bien guardado como lo estuviera largo tiempo el del primer De Chirico" 99 . Tras el texto, se abre la nueva genealogía de la pintura surrealista y sus logros de actualidad. Le Cerveau de 13.

97 BRETON, A. (1939, mayo). Prestige d'André Masson. Minotaure, 12-13, 13-15, 2 ilust. (Masson), p.

98 BRETON, A. (1939, mayo). Des tendances les plus récentes de la peinture surréaliste. Minotaure, $12-$ 13, 16-21, 14 ilust., p. 16.

99 Ibidem., p. 17. 
l'Enfant de G. de Chirico, que fuera la primera imagen de pintura aparecida allá por 1922 en Littérature y tantas veces reproducida después en los medios surrealistas, inicia una serie de la que solo citaré lo destacado en color: Tanguy, efectivamente, y Paalen, Gordon Onslow-Ford, Seligmann, Matta. Imágenes ajenas a simbolismos, de trazo inmediato, que fluyen sin previsión, confirmando lo expuesto por Breton ahora y en artículos como Le Message automatique (n $\left.{ }^{\circ} 3-4\right)$ o D'une décalcamonie sans objet préconçu $\left(\mathrm{n}^{\mathrm{o}} 8\right)^{100}$. Estas recalificaciones del automatismo que superan anteriores retóricas figurativas caracterizan el arte surrealista del fin de década y proyectan al futuro una actitud artística y una suerte de primitivismo entre abstracto y mágico que alcanzará su completo desarrollo tras la guerra: en América y sus expresionismos, pero también en Europa donde el cordón umbilical surrealista nunca se cortó.

[Fig. 22] Méjico ilumina una sombría Europa.- Sorprende la presencia entre los nombrados de una imagen distinta, Ce que l'eau m'a donné de Frida Kahlo, pero se explica como preámbulo del cuaderno mejicano que se abre poco después con una poderosa portada interna debida a Diego Rivera. Souvenir de Mexique ( ${ }^{\circ}$ 11-12) se encuadra a la perfección en el género del relato de viajes. Un Bretón fascinado relata su visión del país: su reciente historia revolucionaria, su cultura de la muerte, los lugares visitados con el muralista mejicano como cicerone. El aporte visual del cuadernillo es parte inseparable de la experiencia que el poeta propone a sus lectores. Un joven muerto cuya sangre empapa la tierra seca sirve de frontispicio al artículo e inicia una larga serie de inspiradas fotografías firmadas por Álvarez Bravo; también el arte de Rivera y, sobre todo, el popular, dulces o pintura tradicional; finalmente, un pliego de intensidad y surrealidad absoluta, en el que se confronta la regularidad repetitiva de unas estancias de trabajo con una insinuante Madame Vaudeville. Uno de los países surrealistas por excelencia desde aquel célebre Le monde aux temps surréalistes ${ }^{101}$, no podía dejar de presentarse maravilloso, más ahora que merecería aumentar su cartográfica hipertrofia surrealista, pues había devenido patria de adopción de Trotsky. Es precisamente la fotografía que capta el encuentro del revolucionario y Breton con Rivera por testigo, cuyas consecuencias fueron ya analizadas, el documento más difundido de Souvenir du Méxique.

En su conjunto este último capítulo de las publicaciones periódicas del surrealismo antes de la invasión de Polonia trasluce un extraño optimismo derivado de los ajustes analizados: por una parte, un arte reorientado, muy reforzado por jóvenes y activo;

100 A lo largo de los tres monográficos ya citados: Picasso, Duchamp y Masson, y más especificamente, en Le Message automatique, en D'une décalcamonie sans objet préconçu o en Des tendances les plus récentes de la peinture surréaliste, Breton decanta una teoría del arte opuesta al control y la acción voluntaria. En Le Message automatique, el más elaborado de sus textos sobre este asunto, se analizan las condiciones de creación en el arte de médiums, como Victorien Sardou y de visionarios como Le facteur Cheval, entre otros. Esta clase de arte, como el de los enajenados presentado por Éluard en Juste Milieu o el surgido mediante técnicas azarosas como la decalcomanía, preconiza y contiene en buena medida la idea de Art brut y otras propias del arte posterior a 1945. No obstante, hay que indicar con Carla Demierre que Breton y el surrealismo tienen estas manifestaciones de lo maravilloso como poderosas afirmaciones del surrealismo, como potencialidad pero no como objetivo poético o artístico cumplido. DEMIERRE, C. (2008). Breton et le mot magique. En YERSIN, V. (Ed.). Op. cit., (48-53, p. 51).

101 El célebre mapamundi distorsionado según el interés surrealista de los territorios. Apareció en Variétés. Le surréalisme en 1929. 

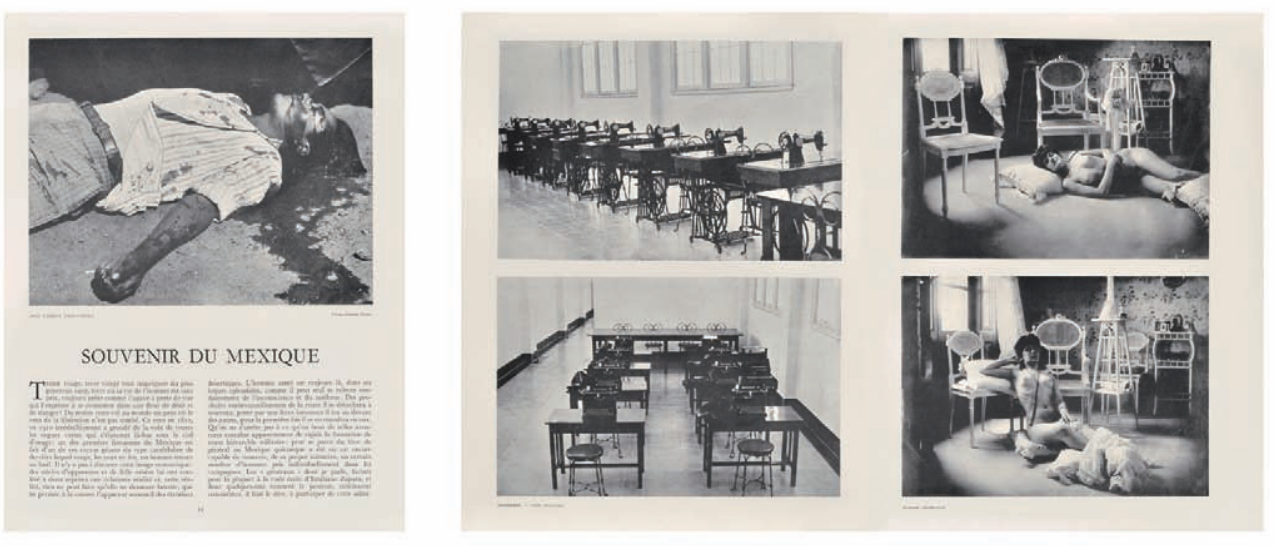

Fig. 22. Minotaure: A. Breton, Souvenir du Mexique, no 12-13, 1939.- a) Pág. inicial del monográfico. Fotografía de Álvarez Bravo; b, c) Pliego de imagen sin referencia de autor: izq. Monterrey. Cité militaire; der. Madame Vaudeville.

por otra, desde la creación de la FIARI, una posición política clara e independiente. Aunque no podamos evitar hoy ver las ruinas de Péret como premonitorias, estos textos de Breton apenas permiten imaginar otra cosa que una paradójica confianza en el futuro del movimiento, aun sabiendo, como hemos comprobado, que a su alrededor el mundo se desmoronaba. Sin embargo, los abandonos y expulsiones se acumulaban: Éluard, el gran amigo, ¿podía continuar el surrealismo sin él?, Char, hacia 1935, Caillois aproximándose a Bataille, Brassaï, incluso Max Ernst que se distancia de la actividad del grupo acabada la exposición de 1938. También Dalí, contra quien ya en 1934 Breton había articulado las acusaciones de índole político que llevarán a su expulsión, aunque salvada entonces gracias a la defensa de una parte del grupo ${ }^{102}$. Ahora se hace al fin efectiva: "Dalí profesa en febrero de 1939 (...) que todo el malestar del mundo es racial y que la solución que ha de prevalecer es, concertada por todos los pueblos de raza blanca, la reducción de los pueblos de color a la esclavitud. No sé qué puertas podrá abrirle tal declaración (...) pero sé cuales le cierra" 103 , afirma Breton en Des tendances les plus récentes de la peinture surréaliste $\left(\mathrm{n}^{\circ} 12-13\right)$ para justificarla, antes de destronar su "monótona" pintura a favor de la de Tanguy. En 1939 Breton no parece preocuparse por lo que deja atrás, sin embargo, no hacía mucho que mandaba buscar a un Dalí que no disimulaba su fascinación por las "irracionales" parafernalias hitlerianas ni su aceptación de Franco, con el fin de garantizar

102 Crevel, Tzara, Giacometti y Eluard se negaron a votar una expulsión ya decidida por buena parte del grupo. Éluard dio sus razones: "(Dalí) Nos ha aportado numerosas ideas nuevas y brillantes, y su pasión por el surrealismo, aunque absolutamente fuera de contexto, es incontestable. Mi tristeza, mi pesimismo surgen al pensar qué podríamos hacer en común, sin él. Él nos ha agitado, deprimido y entusiasmado, lo que es sano" (02/1934). AGUER, M. (2004, junio). La incondicionalitat surrealista de Salvador Dalí a debat. L'Avenç, 292. Recuperado de http://www.salvador-dali.org/serveis/ced/articles/article9.html

103 BRETON, A. (1939, mayo). Des tendances les plus récentes de la peinture surréaliste. Op. cit., p. 17. 
la Exposition Internationale du surréalisme celebrada en la Galerie des Beaux-Arts de París en enero de 1938, último gran acontecimiento colectivo del surrealismo histórico: en ese momento ni tan siquiera Breton podía concebir un evento surrealista sin algo así como el Taxi pluvieux que creara el excéntrico artista para la ocasión.

Más que nunca hablar de surrealismo en 1939 es hablar de Breton que ya no cuenta con contrapesos en el grupo y está convirtiendo al partido del sueño en un monólogo. En tales circunstancias su optimismo al soltar como lastre el material con que se construyó el surrealismo supondrá, ya después de la guerra, una completa refundación, un grupo humano distinto, muy centrado a su alrededor y que apenas sobrevivirá a su muerte ${ }^{104}$. Su propia e inmensa herencia de entreguerras será ampliamente asimilada -también como espectáculo- por el arte y la cultura, pero más allá de su control y participación realmente efectivos. Veíamos cómo Documents inédits sur le Comte de Lautréamont era el último contenido que cerraba mágicamente la colección de Minotaure. El penúltimo, lo firma la Redacción y está vinculado a la FIARI; Le nationalisme dans l'art $\left(\mathrm{n}^{\mathrm{o}}\right.$ 12-13), aunque centrado en lo cultural es, por fin, un texto político en Minotaure: "En Alemania, en Italia, en la URSS, los pinceles y las plumas obedecen a las consignas impuestas por los jefes políticos, sirven a la propaganda, trazan la gloria del amo. En tal régimen el arte muere instantáneamente en esos países" ${ }^{105}$. Como ya comenzaba a morir en Francia, preludio del éxodo surrealista a América.

\section{ESQUEMA:}

1. El surrealismo tras el Segundo manifiesto. Crisis y refundación.

2. Le surréalisme ASDLR: las revoluciones comunicantes.

3. La gran amplificación de Minotaure.

4. Primer interludio: Documents 34. Interventions surréalistes.

5. Minotaure 1935, la poesía. Contre-attaque, el antifascismo.

6. Segundo interludio: Cahiers d'art: revista de arte surrealista.

7. El objeto surrealista en las revistas.

8. Minotaure 1936: surrealismo vs. crítica de arte.

9. Minotaure $3^{\mathrm{a}}$ serie. Lentamente, hacia el final de una era.

10. La revista con cabeza de animal: surrealismo proyectado al futuro.

\footnotetext{
104 La actividad del grupo surrealista continuó manifestándose a través de la publicación periódica: $V V V$, revista bilingüe émula de Minotaure, editada en Nueva York con el asesoramiento de Breton, Ernst y Duchamp, 4 números entre 06/1942 y 02/1944; Le surréalisme même, revista trimestral muy cuidada e ilustrada, dirigida por Breton, 5 números entre 10/1956 y 04/1959; Bief. “Jonction Surréaliste” boletín del grupo, 12 números entre 11/1958 y 04/1960; La Brèche “Action surréaliste”, revista dirigida por Breton, 8 números entre 10/1961 y 11/1965; además de Néoms, Médium, Front unique, L'Archibras y Coupure. A partir del análisis de tal riqueza editorial de grupo, en BONNET, M. y CHÉNIEUX-GENDRON, J. (1982). Revues surréalistes françaises. Autour d'André Breton 1948-1972. Millwood, New York: Kraus International Publications, se defiende la existencia de un surrealismo vigoroso tras la Segunda Guerra Mundial. Resulta, sin embargo significativo que ninguna de estas cabeceras, a diferencia de todas las de entreguerras, cuente con reimpresiones ni estudios extensos. Esta cuestión se aborda en MAZZEI, L. Le surréalisme "maudit" à travers ses revues (1939-1969), artículo alojado en Mélusine: http://melusine.univ-paris3.fr/astu/Mazzei.pdf.

105 Rédaction. (1939, mayo). Le nationalisme dans l'art. Minotaure, 12-13, 70-71, p.70.
} 